Baltic-Pontic Studies vol. 21: 2016, 27-53

ISSN 1231-0344

DOI 10.1515/bps-2017-0011

Marcin Lawniczak*

\title{
MICROSPATIAL ANALYSIS OF SELECTED EARLY SCYTHIAN FORTIFIED SETTLEMENTS IN PODOLIA
}

\begin{abstract}
There are two levels of detailed characteristic of the aforementioned sites. The first is the construction aspect, such as the area of the site (within the fortifications only) and the shape of the fortifications. The second level of detailed characteristics is description and presentation of the natural factors surrounding the sites, such as landforms and its location regarding to watercourses and watersheds.
\end{abstract}

ABSTRACT

Key words: microspatial analysis, fortified settlements, Podolia, Scythian time, Early Iron Age

INTRODUCTION

For the purpose of this paper six archaeological sites were analysed. Three of them were in the basin of the Dniester (Rudkivtsi [Рудківці], Hryhorivka [Григорівка], Rukhotyn [Рухотин]) and another three were in the basin of the Southern Bug (Severynivka [Sewerynówka - Северинівка], Yakushyntsi [Jakuszyńce - Якушинці], Nemyriv [Niemirów - Немирів]). In each case several characteristics such as natural environment (landform, distance from watercourses), as well as the form and measurements of the settlement fortifications have been

* Institute of Archaeology, Adam Mickiewicz University, Umultowska 89D, 61-614 Poznań, Poland, e-mail:m.lawniczak88@gmail.com 
discussed. For the purpose of site analysis maps in the scale of 1:10000 have been used. They were digitalised afterwards to create raster maps and 2.5D models.

\section{DATA SOURCES}

Most of the images were created with ArcGIS software and maps on the scale of 1:10000, were purchased from the Ukrainian Geographical Archive. They were produced in the second half of the 1980s by Department of Geodesy and Cartography in the Soviet Union (Главное управление геодезии и картографии при Совете Министров СССР). The geodetic data applied was Pulkovo 1942 with contours within 1 and 2 metres. It was used to create a digital elevation model (DEM) for six fortified settlements and their surroundings in the Podolia region. Maps were georeferenced, and continuous data, such as watercourses and contours, was digitised and represented by vector (polyline) forms. The spatial interpolation of points for DEM was performed. Unfortunately, said maps represented features such as fortifications in a simplified and schematic way, in the form of a symbol and their numeral height with reference to the surrounding area. What is more, most maps did not include information on the exact location of the fortified settlements which then needed to be acquired from the 1:100000 maps. Exceptionally, maps did not include any information on gords (Hryhorivka, Pereorky) or they were incorrectly represented (Yakushyntsi), which caused the necessity for further consultations with representatives from the Institute of Archaeology of the National Academy of Sciences of Ukraine to learn their measurements and shapes as well as their location based on satellite images (http://google.com/maps, http:// wikimapia.org access 10.05.2015). Three additional images (two for the Severynivka settlement and one for the Nemyriv settlement) were created with ArcScene software from aerial photogrammetry-based point clouds.

\section{GENERAL CHARACTERISTICS OF THE SITES}

When you compare the above-mentioned fortified settlements the first distinction to appear is the shape of their fortifications. They can be categorised as: rect- 
angular, two-part and oval. Each of these types was found in the basins of the main rivers (Tab. 1).

The second distinctive element is the geographical placement of the fortification, to which the shape of the fortifications is related. Rectangular fortifications are located on river forelands with steep slopes. The natural advantages of this location were known and used in the fortified settlements construction process. High and very steep, almost vertical embankments provided enough protection and therefore constructing fortifications that would fully surround the settlement was not necessary. The terminology used here is related to the shape of the fortified settlements, which in case of the two analysed sites resembles a rectangle or a square.

Another group contains two-part sites, which are located on less steep slopes of the river basins. These sites are divided into two separate parts - the proper gord and borough therefore the terminology of two-part sites was suggested for this paper.

The last group can be characterised as the oval sites, and are recognisable by the oval or round shape of the singular ramparts surrounding them. Those sites are also the largest.

It is hard to evaluate which factor determined the construction of particular types of fortifications while it seems to be possible to build each of them in the area of interest (Fig. 1 and 2.). It is probable that it was conditioned by the functional aspect but there are not enough case studies on the subject to conclude or recreate it.

\section{DETAILED CHARACTERISTICS OF THE SITES}

There are two levels of detailed characteristics of the said sites. The first is the construction aspect, such as the area of the site (within fortifications only) and the shape of the fortifications. For the fortified settlements such as Yakushyntsi, Rudkivtsi, Rukhotyn and Hryhorivka visual presentations of sections were prepared in ArcMap 10.2 based on DEM's produced using topographic maps in the scale of 10000. Because of the high inaccuracies of those maps all measurements needed to be treated as approximate and all site areas were averaged to half of a hectare. In case of the Severynivka and Nemyriv fortified settlements detailed information on the sites and their fortifications measurements was presented in a separate paper as more accurate data in the form of aerial photogrammetry-based point clouds was acquired.

The second level of detailed characteristics is the description and presentation of natural factors surrounding the sites, such as landforms and its location regarding watercourses and watersheds. 
$\mathrm{T} a \mathrm{~b} \mid \mathrm{e} 1$

Macrospatial placement of fortified settlements

\begin{tabular}{|l|l|l|l|}
\hline Site & Fortifications & Placement & $\begin{array}{l}\text { River } \\
\text { Basin }\end{array}$ \\
\hline Severynivka & Rectangular & Elevated foreland & S. Bug \\
\hline Yakushyntsi & Two-part & Identifiable diversity - flat and partially sloped ground & S. Bug \\
\hline Nemyriv & Oval & Relatively flat ground & S. Bug \\
\hline Rudkivtsi & Rectangular & Elevated foreland & Dniester \\
\hline Hryhorivka & Two-part & Identifiable diversity - flat and partially sloped ground & Dniester \\
\hline Rukhotyn & Oval & Relatively flat ground & Dniester \\
\hline
\end{tabular}

Source: own elaboration

3.1. SEVERYNIVKA

This archaeological site is located on the verge of one of the arms of the Dniester and Southern Bug watersheds (Fig. 3), near the town of Mezhyriv. The hillfort towers above the basin of the Riv river (the right confluent of the Southern Bug) and is 5.5 hectares wide. The settlement was square-shaped and protected on the east side by shafts running perpendicularly to each other from the north-east and south-east directions, while from the west, north-west and south-west its boundary was defined by steep slopes descending towards the river (Fig. 5 and 6).

It is possible that fortified settlements had access to land routes, described in the paper "Macro-spatial analysis of early Scythian settlements in the right-bank of Ukraine" through a smaller, south-east watershed (the site is located at its end). Perhaps there was also a second connection running towards the settlement in Yakushyntsi, leading through a picturesque promontory located at the confluence of the Dum and Dumka rivers, $1700 \mathrm{~m}$ east of the settlement. Currently the river surrounding the promontory is piled up by a dam located at its source. It is difficult to assess what this area looked when the gord was functioning (Fig. 4).

The archaeological research did not give the answer to the question of how water was sourced / provided. The site was located on high ground (Fig. 7) and it is doubtful if deep enough wells could have been dug in there. There might have been some kind of natural or anthropogenic reservoirs that could accumulate water from rain and thaw. If so, they probably were not able to satisfy all of the needs of the people living in this gord for a longer period of time. Accordingly, it can be assumed that under normal conditions (i.e. absence of external threats) livestock such as cattle, horses, etc., grazed at the local pastures, near waterholes. One of the places where they could have reached the area by the river was located $400 \mathrm{~m}$ to the north-east (in a straight line) of the site and it is still used in the same way by local farmers (own observation). 


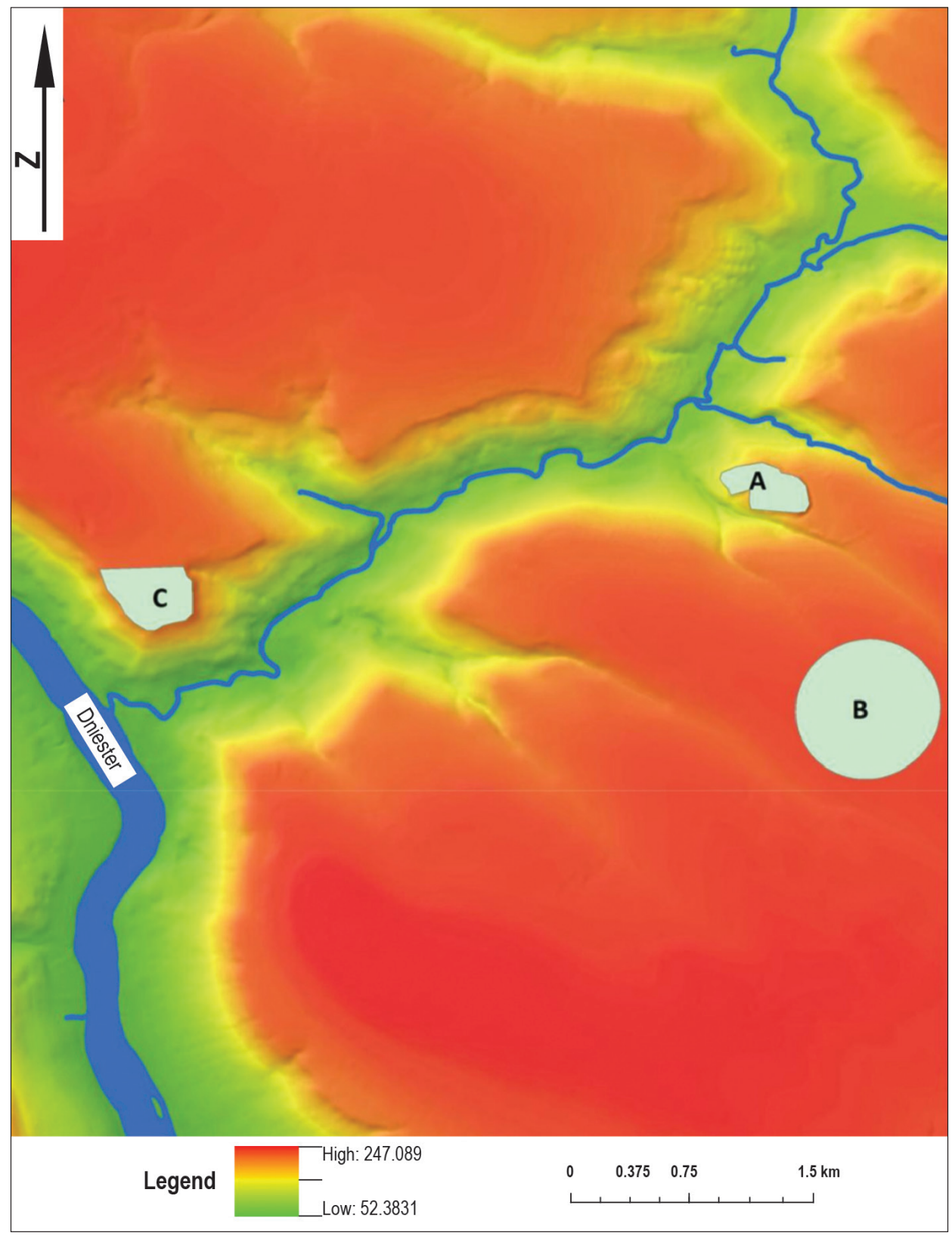

Fig. 1. Presentation of possible alternative locations for the fortification systems in the area of the Hryhorivka site. A - the fortified settlements in Hryhorivka, B - a convenient place for an oval form, $\mathrm{C}-\mathrm{a}$ convenient place for rectangular form. Source: Author's work 


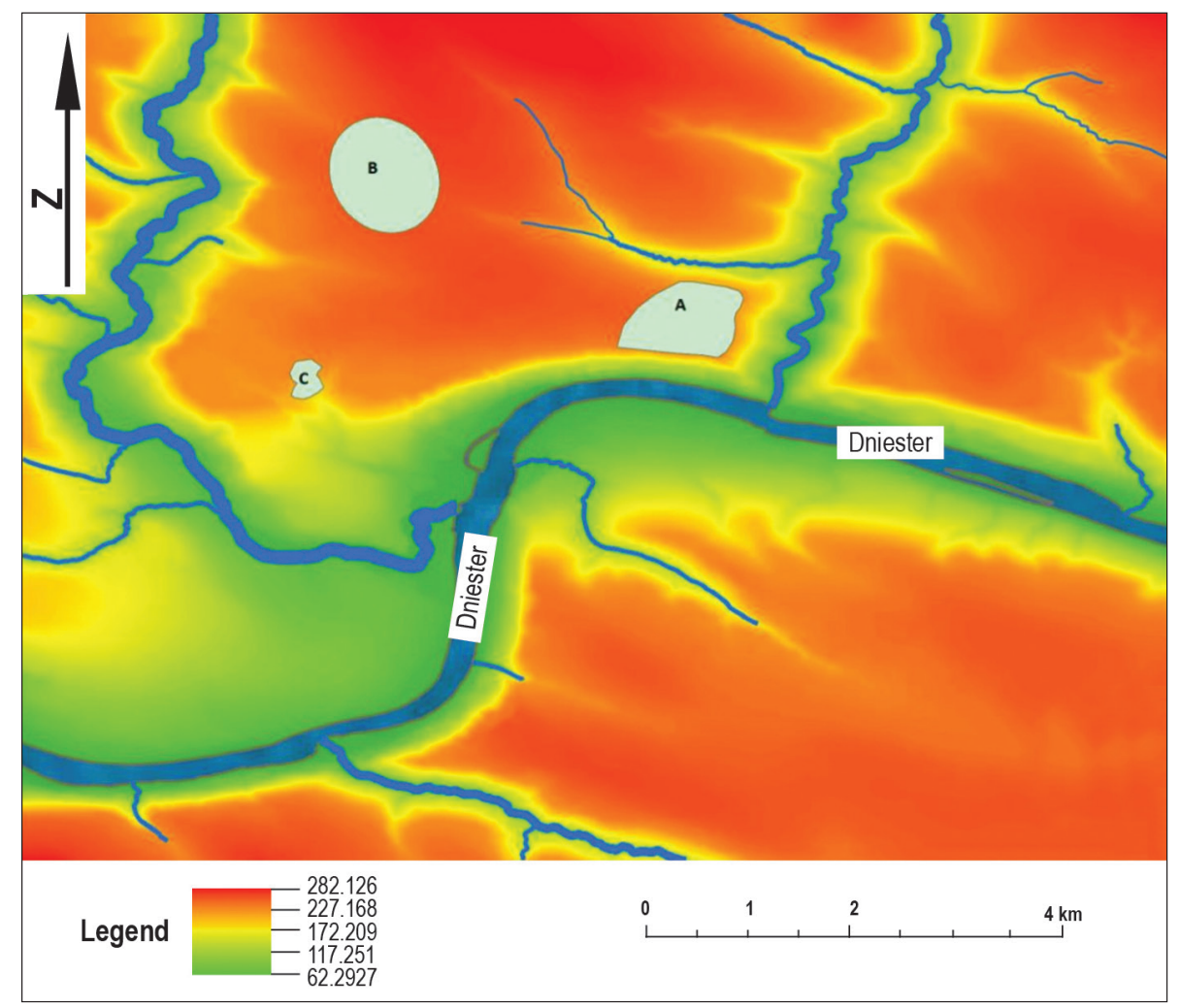

Fig. 2. Presentation of possible alternative locations for the hillfort fortification systems in the area of the Rudkivtsi site. A - the fortified settlement in Rudkivtsi, B - a place suitable for an oval form, $\mathrm{C}$ - a place suitable for the two-part form. Source: Author's work

The second of the rectangular sites is Rudkivtsi, located by the river Dniester (Fig. 8). This gord covers the area of 40.5 ha and is surrounded by natural slopes on three sides (Fig. 9). From the north they run into the watercourse of the $2^{\text {nd }}$ order (numerical division...), to the depth of $90 \mathrm{~m}$ (Fig. 10). From the east they run into the watercourse of the $1^{\text {st }}$ order (direct Dniester inflow), $140 \mathrm{~m}$ deep (Fig. 11). And, finally from the south to the Dniester itself, with a depth of 170 m (Fig. 12).

Fortifications are relatively poorly preserved (probably because of the current settlement), they stretch along the eastern slope slightly to the north, and their fragments can be seen from the west (Fig. 13). It is probable that they originally encircled the whole settlement from those three sensitive directions, as the water- 


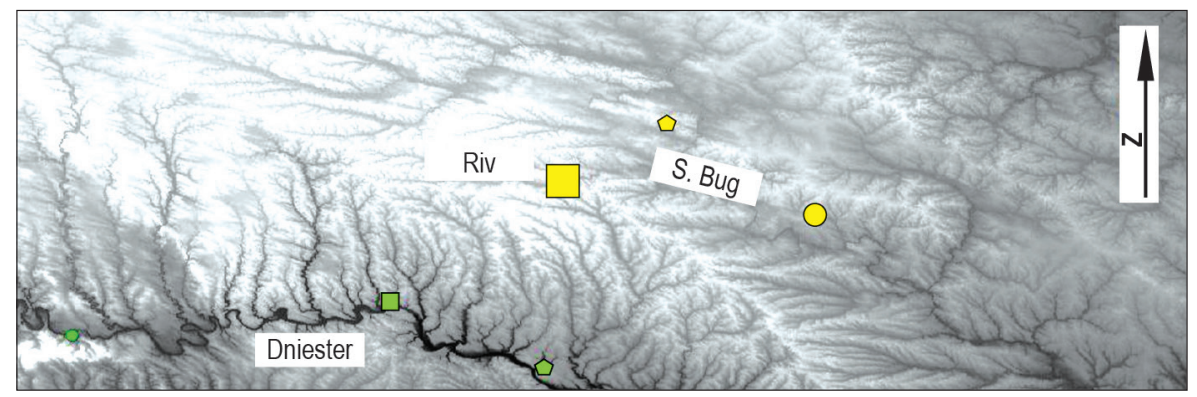

Fig. 3. Location of the site in Severynivka compared to the other analysed sites. Source: Author's work

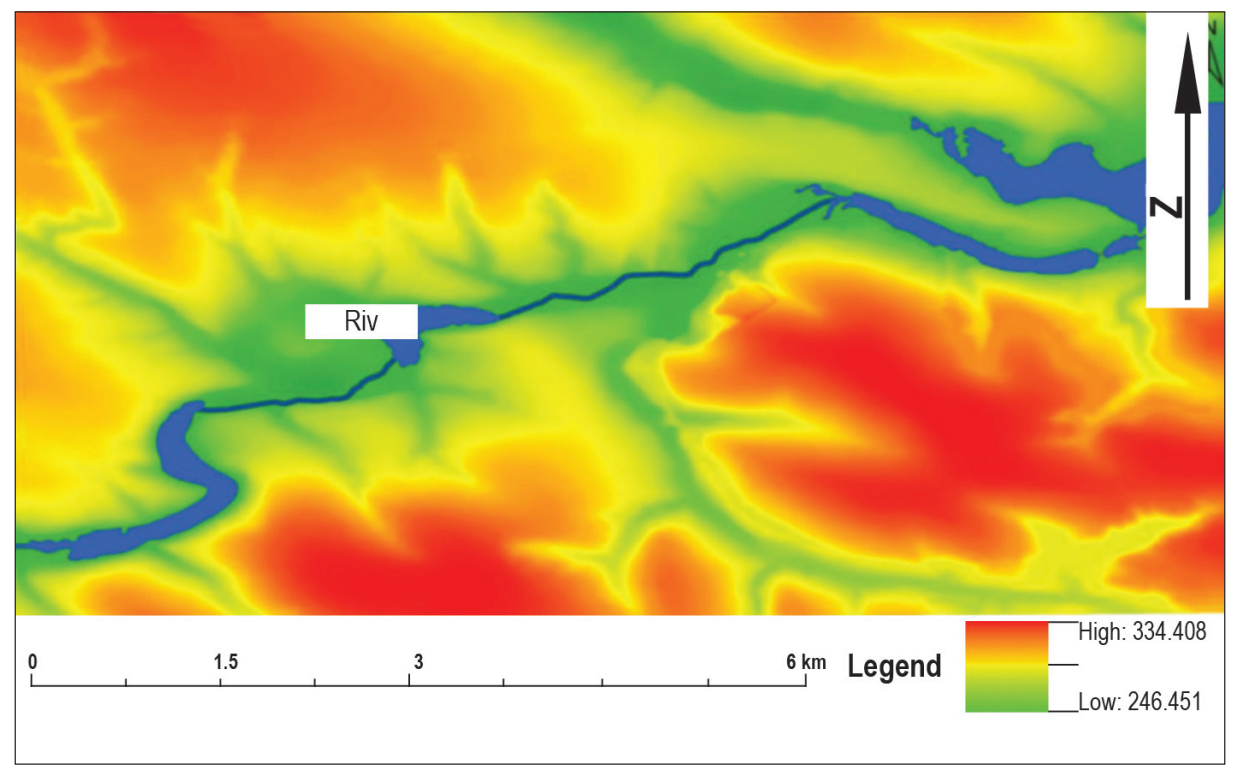

Fig. 4. A fortified settlement in Severynivka with surrounding area. River Riv flows from the south-west to the north-east. River Dumka streams into it just behind the tip that is visible in the north-eastern part of the drawing. Source: Author's work

shed on the west is relatively flat, shallowest from the north of the slope and the least steep on the east. Only the access from the south required no fortification, as wide the river and exceptionally difficult approach prevented possible aggressors from accessing the settlement [Hutsal 2000].

Similarly as in Severynivka, the land road leading from the gord in Rudkivtsi and linking the settlement to the rest of the settlement system is closely connect- 


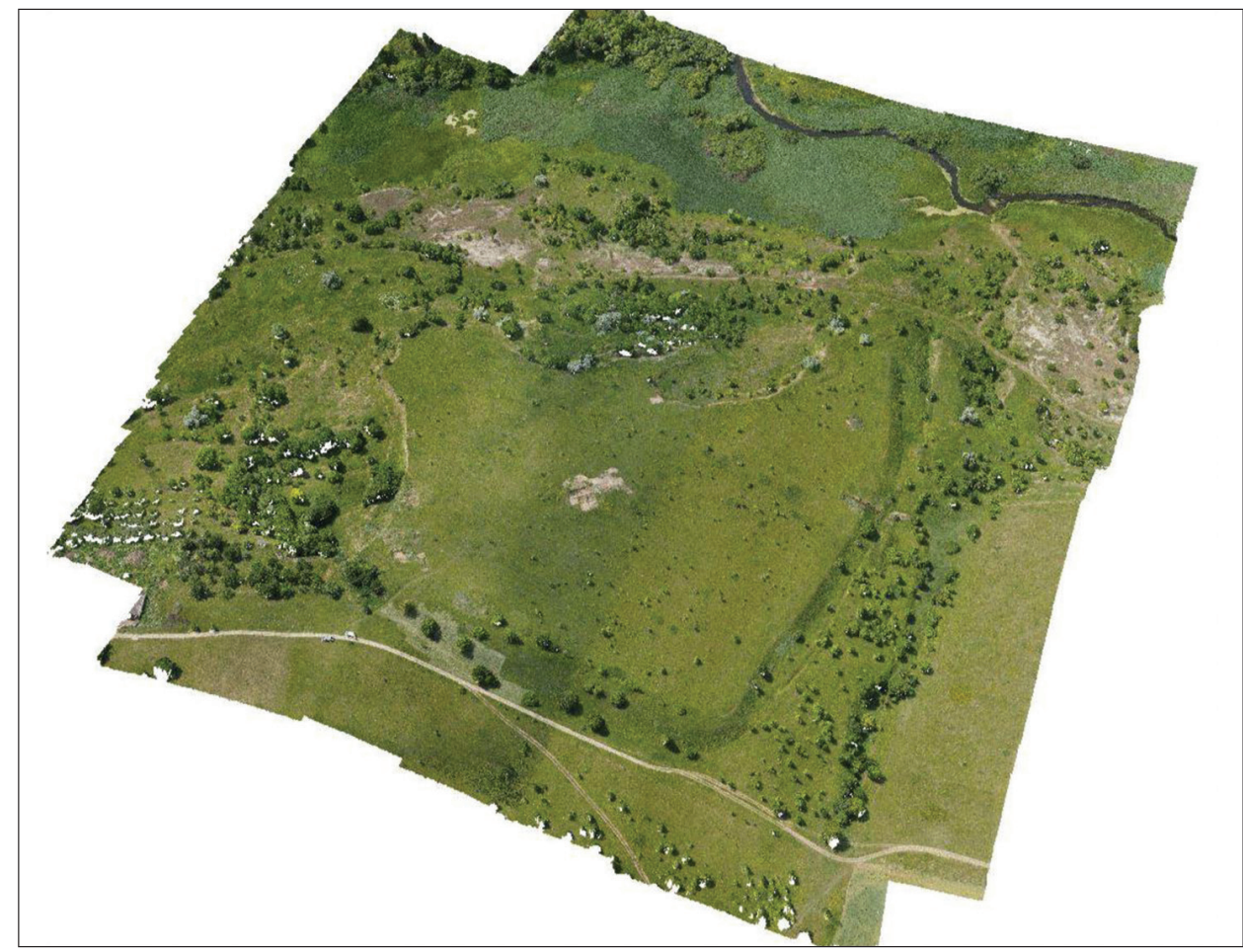

Fig. 5. Severynivka, Vinnytsia Oblast. Point cloud representing the fortified settlement from the west side. Source: Author's work

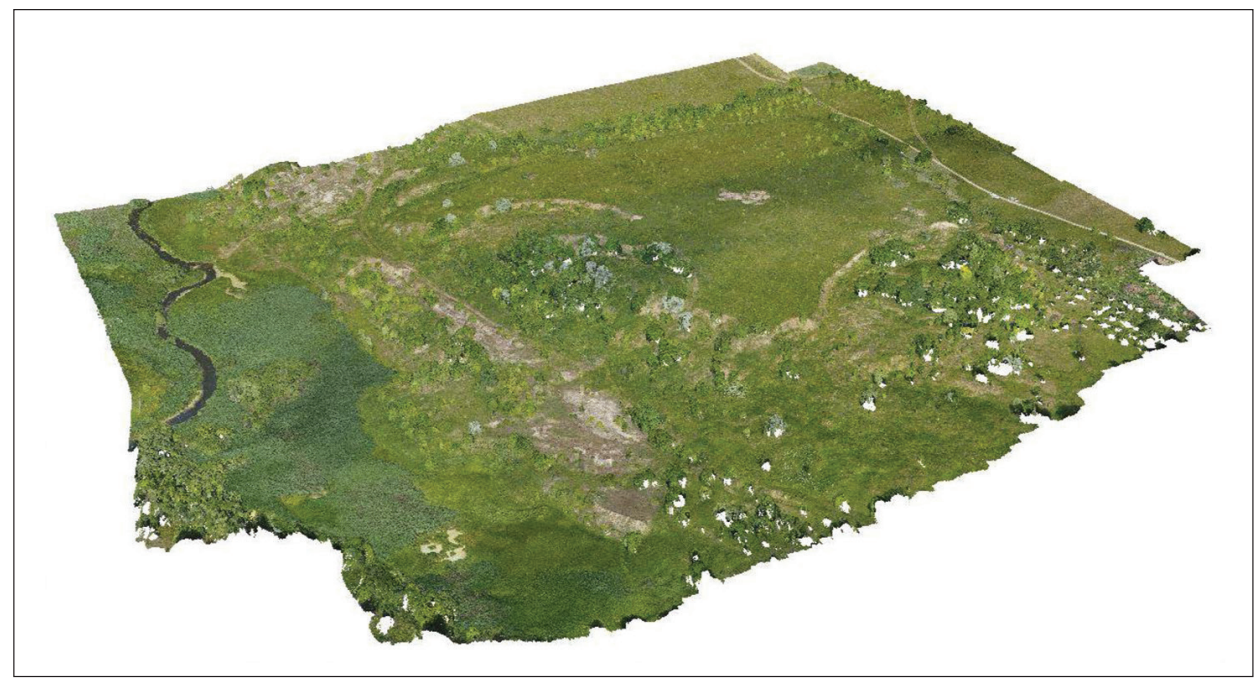

Fig. 6. Severynivka, Vinnytsia Oblast. Point cloud representing the fortified settlement from the east side. Source: Author's work 


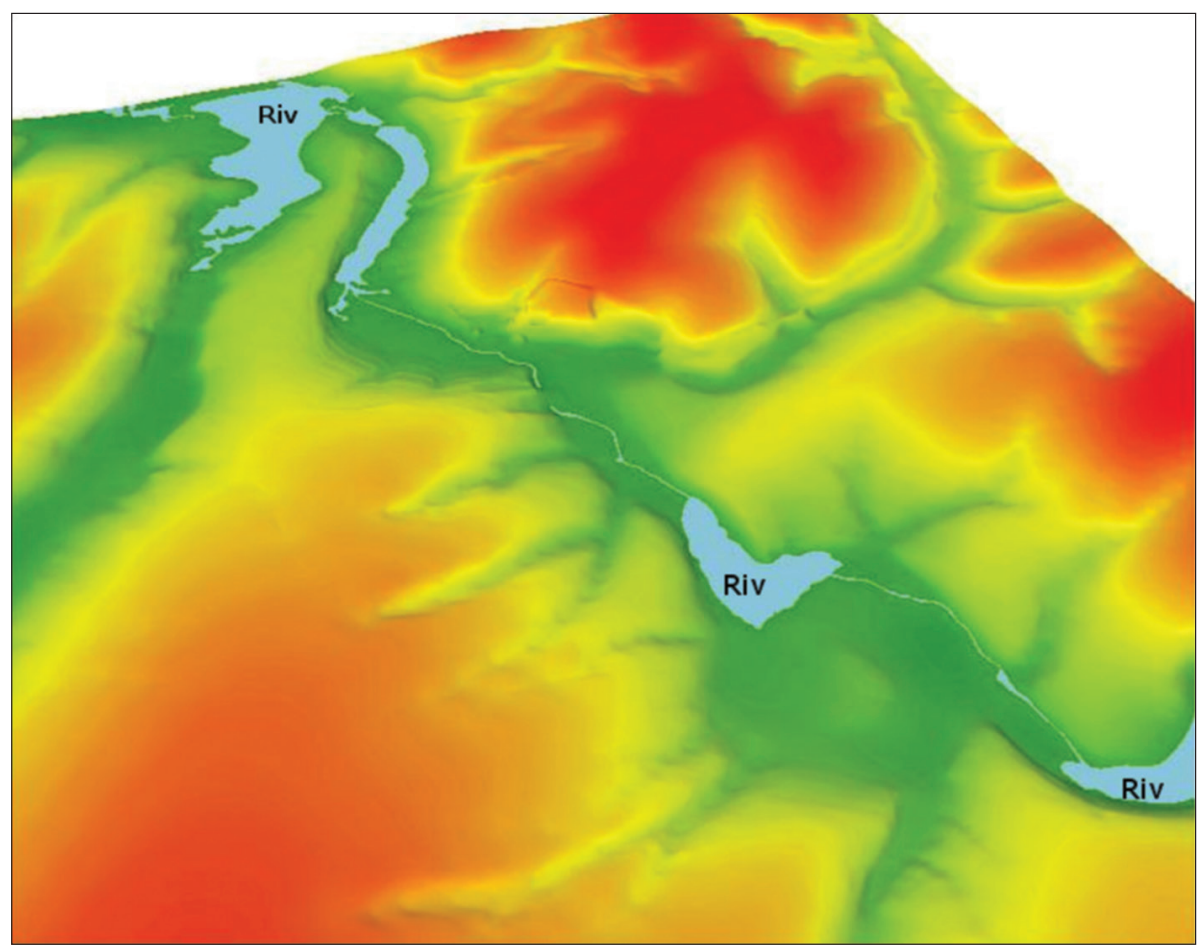

Fig. 7. Severynivka, Vinnytsia Oblast. 2.5D model representing the surroundings of the fortified settlement from north-western side. Source: Author's work

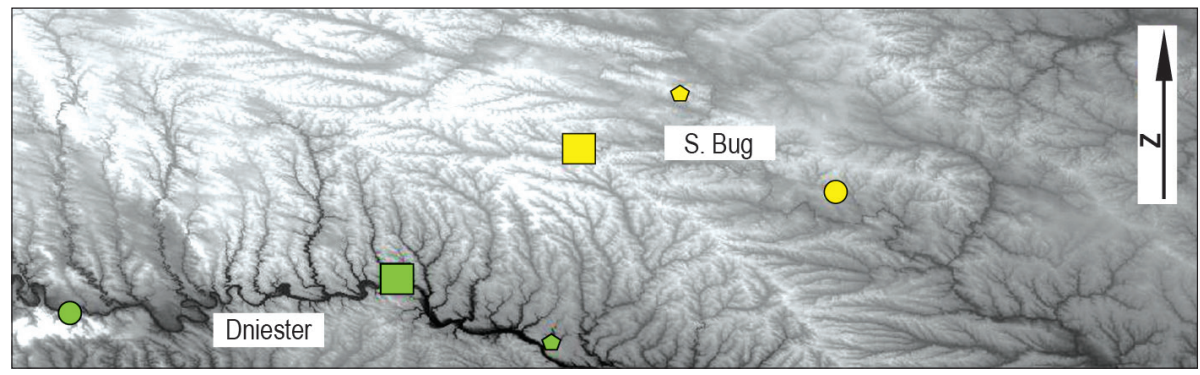

Fig. 8. Location of the site in Rudkivtsi compared to other analysed sites. Source: Author's work

ed to the landform and at first leads north-west for about $2 \mathrm{~km}$ (Fig. 14) then changes its direction to the north near the site in Matsiorsk, and finally reaches the Trans-Dniester route. As in the Severynika case, it is hard to imagine that the settlement was self-sufficient in terms of the water supply. In this case, however, 


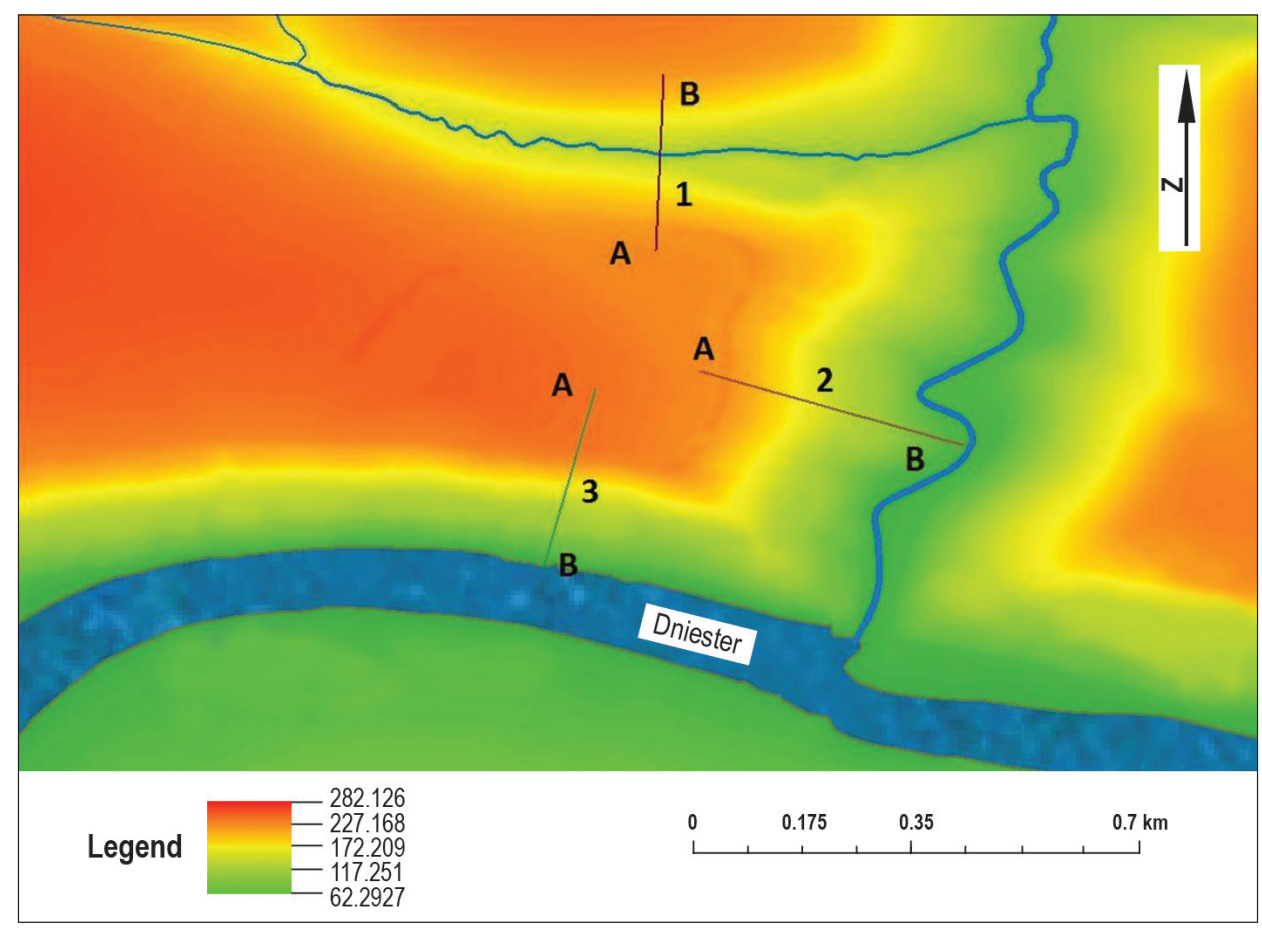

Fig. 9. Locations of the embankment sections surrounding the fortified settlement in Rudkivtsi. Source: Author's work

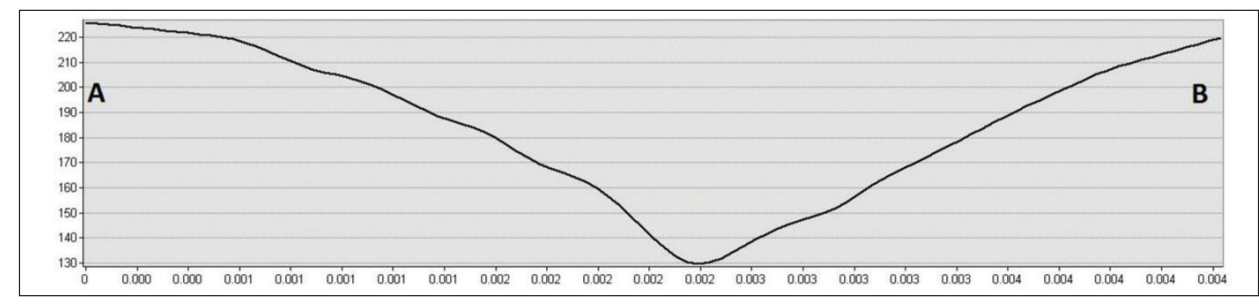

Fig. 10. Rudkivtsi, Khmelnytskyi Oblast. Section 1 of the northern embankment. Source: Author's work

there might have been two places to reach the rivers, one with rather steep cliffs in the east and the other in the west, around a $2.5 \mathrm{~km}$ walk along the mild slope of Dniester (Fig. 15). It can be assumed that such a convenient and vast area by the river could have been suitable for constructing the harbor (Fig. 14) but without archaeological research it is difficult to verify this thesis. 


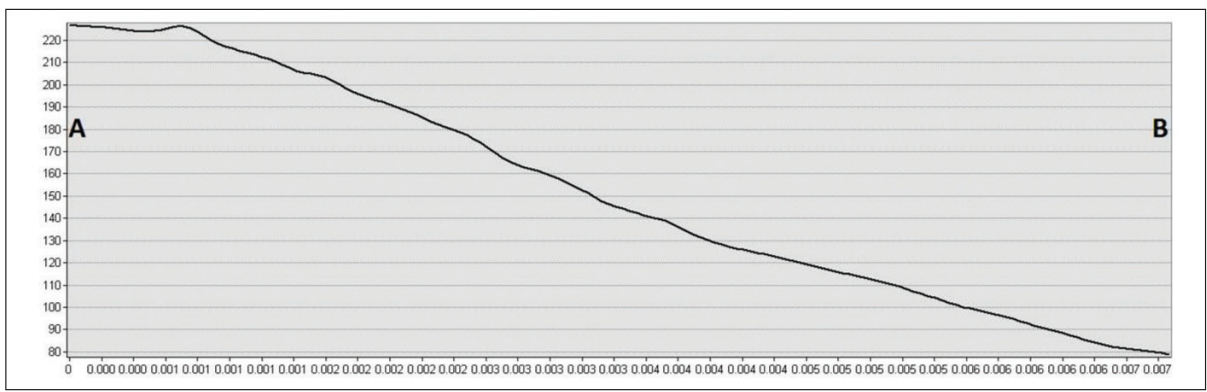

Fig. 11. Rudkivtsi, Khmelnytskyi Oblast. Section 2 of the eastern embankment. Source: Author's work

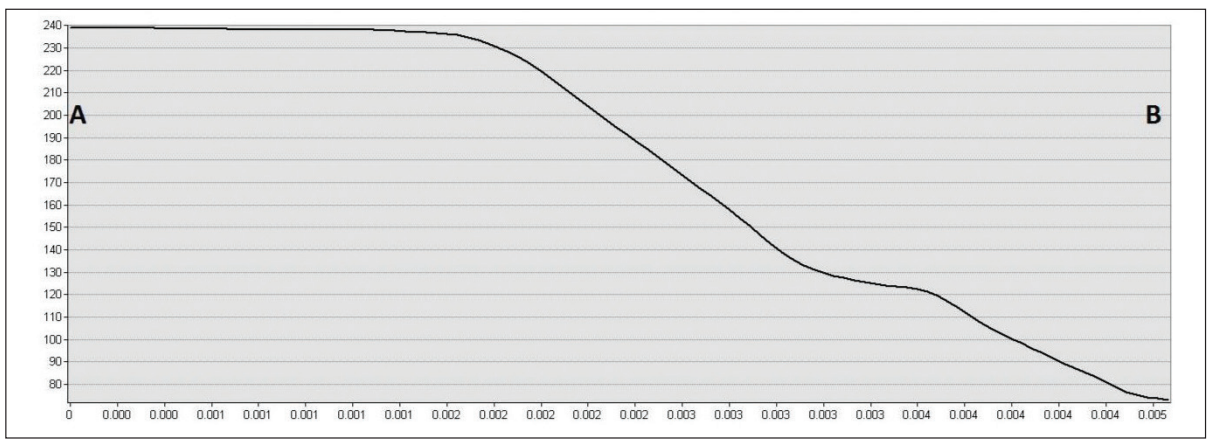

Fig. 12. Rudkivtsi, Khmelnytskyi Oblast. Section 3 of the southern embankment. Source: Author's work

The site is located $7 \mathrm{~km}$ west of the Southern Bug (Fig. 16) and $3.4 \mathrm{~km}$ south-west of another fortified settlement known as Pereorky (Fig. 17). The site is divided into two segments, a settlement surrounded by two rings of ramparts, covering the area of less than 6 ha and a borough of 6.5 ha. The total area of the entire site is less than 12.5 ha.

The fortress is located on the higher ground and towers over the borough located in the lower part of the area, in the east (Fig. 18). The fortifications around the borough surround them not only from the east, but they also partially enter the proper fortified settlement in the south, creating an impressive triple fortification line. In this area one can also find a break in the fortifications, which can be interpreted as the original gates. A ravine begins near this place, running towards the stream confluent of the Southern Bug (Fig. 19). 


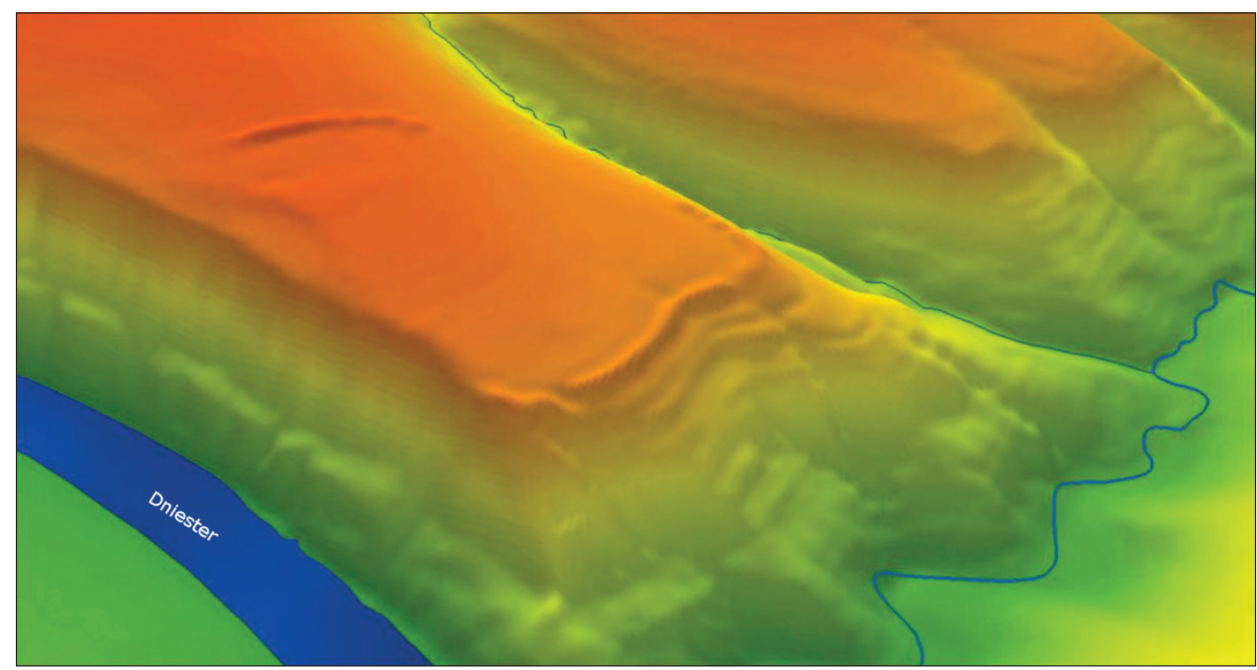

Fig. 13. Rudkivtsi, Khmelnytskyi Oblast. 2.5D model representing the fortified settlement from the south-east. The fortification remains were presented as they show today. Source: Author's work

The proper gord was situated on a relatively flat ground (3 $\mathrm{m}$ in difference), which made it suitable for living, while the borough was located in a slightly sloping area and it seems it was more suitable as a place for livestock due to better air circulation (Fig. 20). Knowing the customs of the Scythians [Herodotus, IV] it can be assumed that if a trading trail was indeed located there it must have been warming with cattle and horses. In such a situation, if the settlement was supposed to support this route it must have been well prepared for keeping the livestock.

Extremely strong fortifications of the gord and the close vicinity of the second gord in Pereorky (Fig. 21), which also had a borough (oral information by Shelekhan), and their common critical position (see Macro spatial analysis of the early Scythian fortified settlements in the right-bank of Ukraine) suggests that they could have been forming heavily fortified gates protecting the Southern Bug crossing. It was an important point on the route between the fortresses on the Dniester and their counterparts located near the Dnieper River. It is difficult to assess now whether this arrangement of two adjacent settlement had the purpose of military protection of the passage or of a caravan service in the situation of blockade, perhaps, resulting from, the accumulation of water after the spring thaw. The layout does not exclude any of these options, but it may well have been determined by such a specific location, for quite different reasons. 


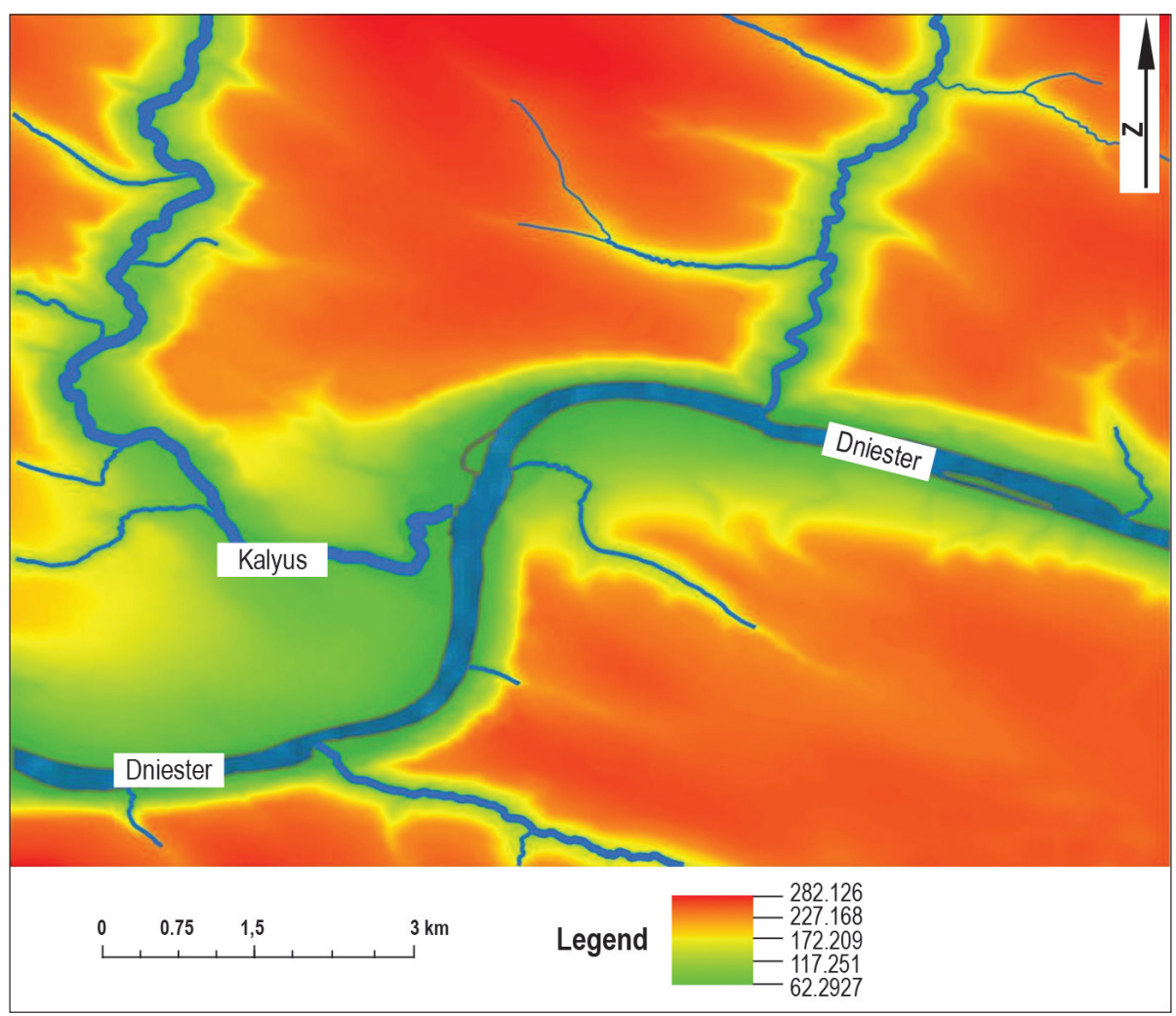

Fig. 14. The fortified settlement in Rudkivtsi with its surrounding area. The deep valley of the Dniester is showing in the centre. There is one place, near in which the largest visible tributary flows into Dniester, and it was likely to be easily accessible from the site. Such a convenient place by the river could have served as a place for grazing or as a harbour. Source: Author's work

\subsection{HRYHORIVKA}

This gord is located in the westernmost part of the Dniester Region (Fig. 22). It is located on the edge of the elevated landform, a tip between two ravines descending into the valley of the river Kotlubaivka (Fig. 26). This river is the left tributary of the Dniester, which flows $3 \mathrm{~km}$ southwest of the site (Fig. 23). The site is similar to the one in Yakushyntsi and is divided into two parts, but with only one line of fortifications around the proper gord (Fig. 24). In addition analogically to the previously described site, the proper gord towers above the borough and is located on a relatively flat ground, in contrast to the additional part located on the slope and descending towards the river. The difference in height for these parts is as $30 \mathrm{~m}$ 


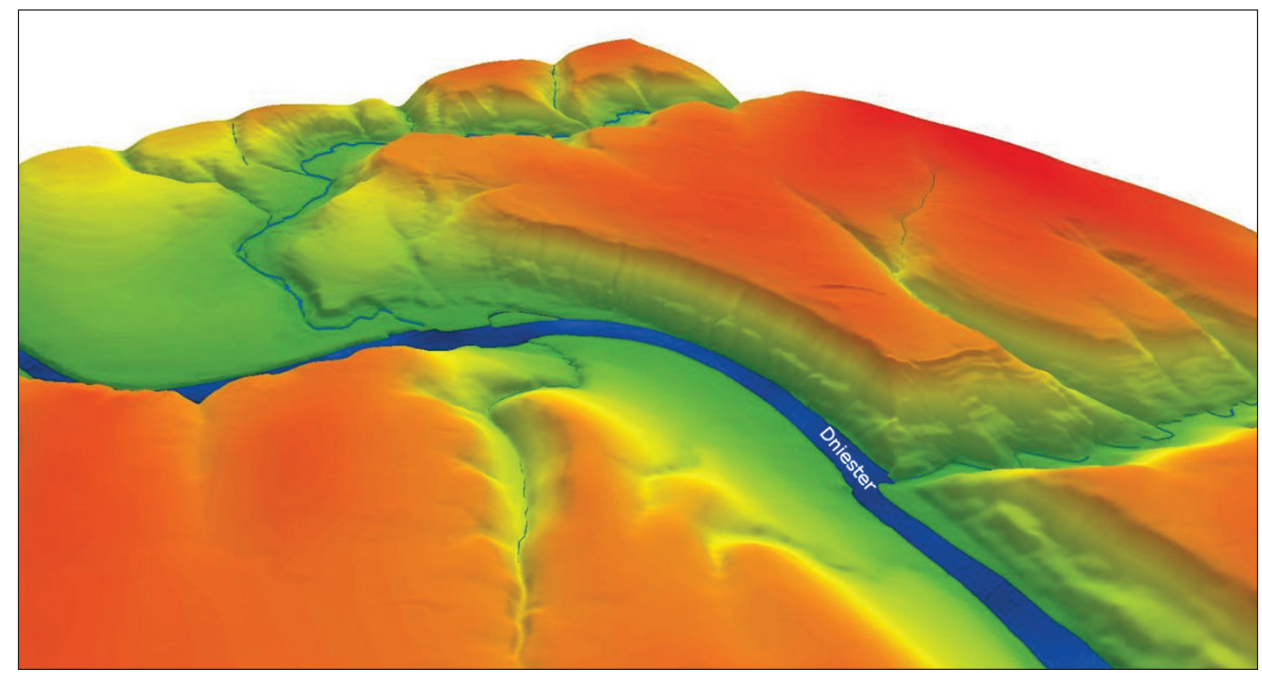

Fig. 15. Rudkivtsi, Khmelnytskyi Oblast. 2.5D model showing the fortified settlement and its south-eastern surroundings. Source: Author's work

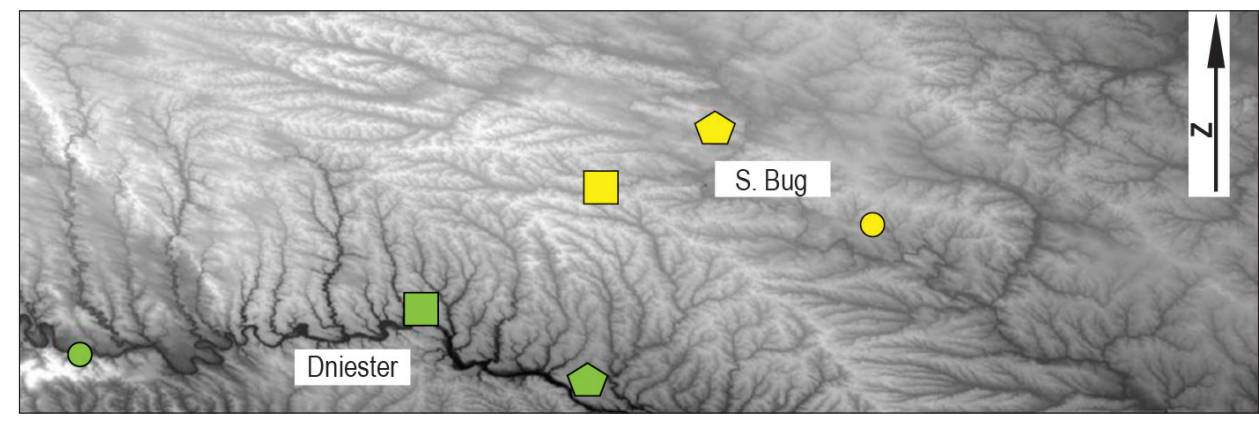

Fig. 16. Yakushyntsi, Vinnytsia Oblast. Location of the site compared to other analysed sites. Source: Author's work

and its slope is $22.7 \%$ (Fig. 25). The settlement covers the area of 10 ha, while the proper fortress is 5.5 ha and the borough is 3.5 ha.

Similarly as in Yakushyntsi, the division of the site in Hryhorivka can be interpreted through the distinction between the proper gord as a residential and craft zone and the borough as a farmhouse. 


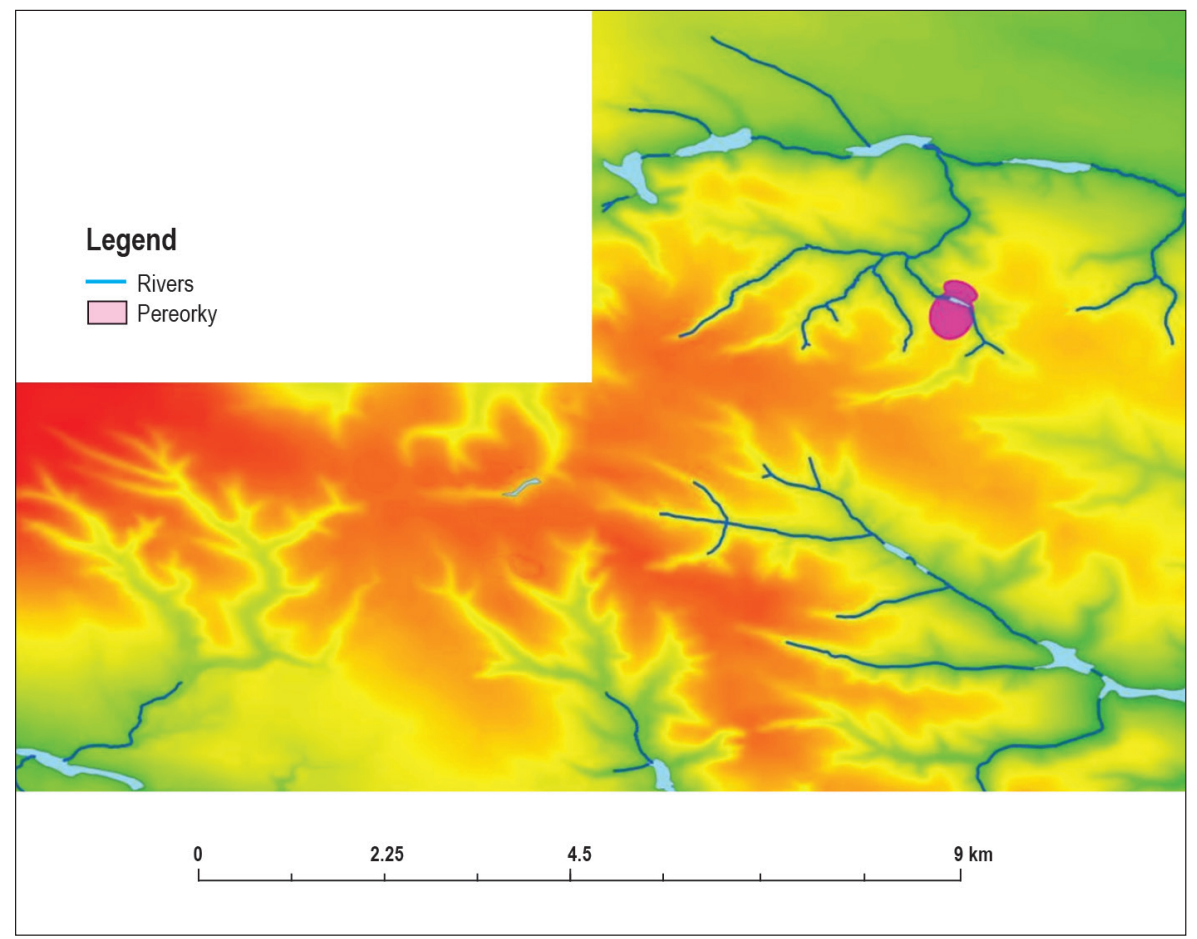

Fig. 17. The fortified settlement in Yakushyntsi with surrounding area and marked location of the gord in Pereorky. Source: Author's work

The settlement is situated on relatively flat ground among the wetlands, $12 \mathrm{~km}$ north of the Southern Bug. It is the only defensive settlement in the Podolia area, situated on the left bank of this river (Fig. 27). The site with fortifications covers the area of 125 ha making it the largest gord in the region. Its shape is mostly oval and cut in the middle by the Ustia, River flowing from the west (Fig. 28). A part of the site, located south of this watercourse covers the area of 59 ha and is divided by three smaller streams running from the south. This divides the entire area into four "districts" (Fig. 29). The area north of the river is 76.5 ha, and is also cut by two natural ravines dividing it into three parts from north to south. The middle section is separated by an artificial ditch with a depth of up to $3 \mathrm{~m}$ separating the central area from the fortifications (Fig. 29). This place is known as "Castle" [Daragan 2010], it resembles a shoe in shape and covers an area of 16.5 ha (Fig. 30). Summarising, eight "districts" can be distinguished at the site 


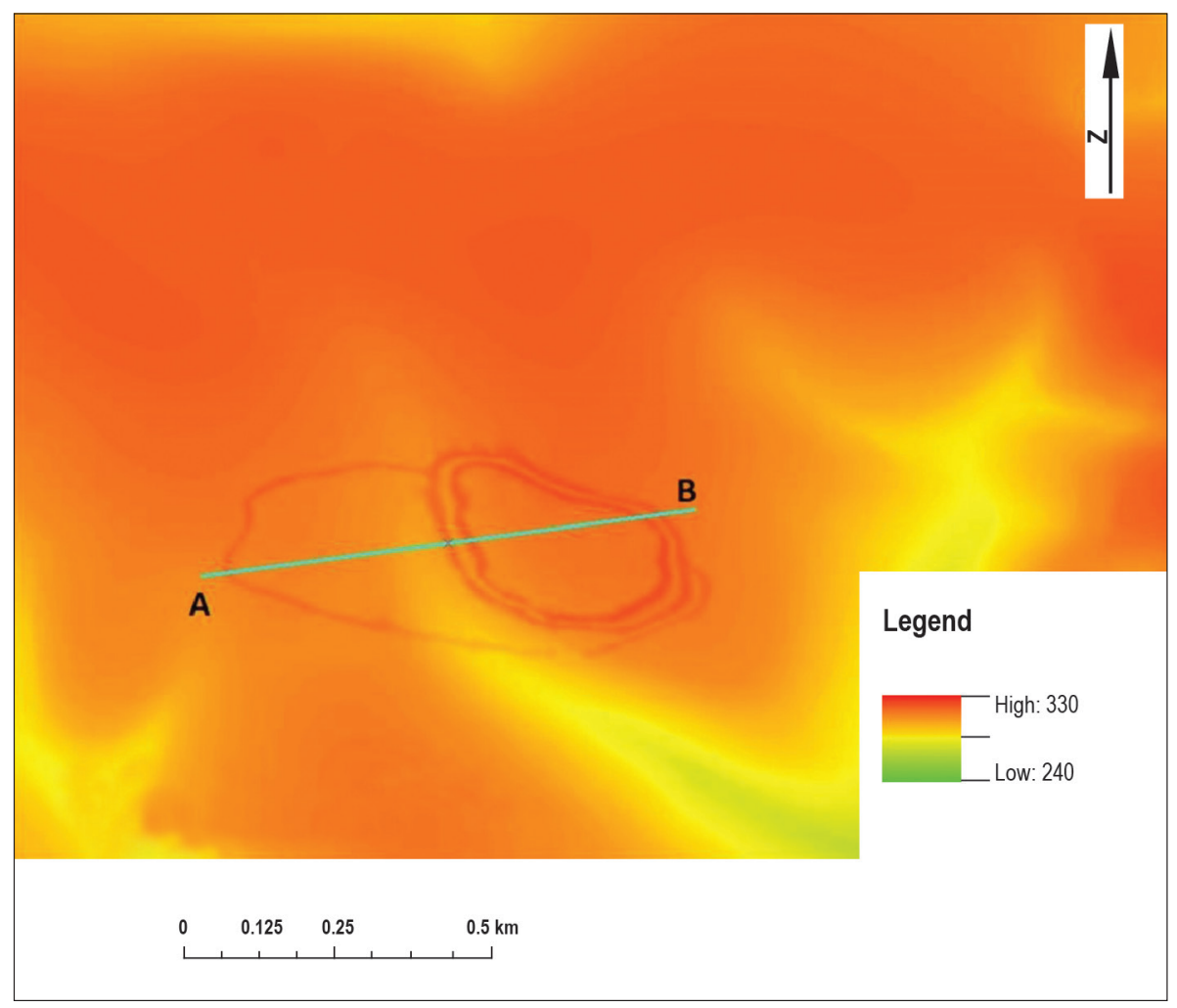

Fig. 18. Location of the section of the fortified settlement in Yakushyntsi. The elevated ground of the proper fortified, compared to the borough, is also visible. Source: Author's work

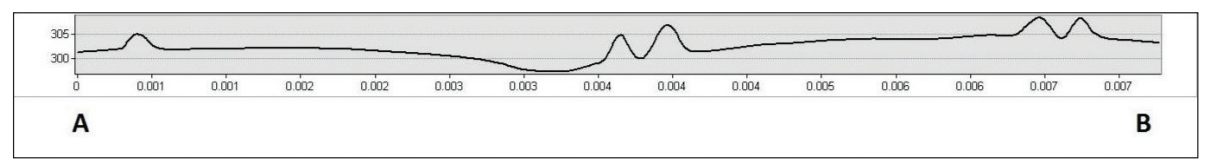

Fig. 19. Section of the site in Yakushyntsi. Source: Author's work

itself (Fig. 29), however it is difficult, without the more advanced archaeological research to determine whether this division was purely natural or whether it played a role in the functioning of the settlement. Nevertheless, it can be assumed with certainty that "Castle" was a unique place, as proved by the fact that, unlike the rest, it was separated intentionally rather than by natural factors. In this case, also without proper archaeological research, it is difficult to specify the exact function of the site; whether it was functioning as a market, a citadel, a place of worship, a governor or elite seat, or maybe it had an older history, and only gradually became the leaven of its present form. 


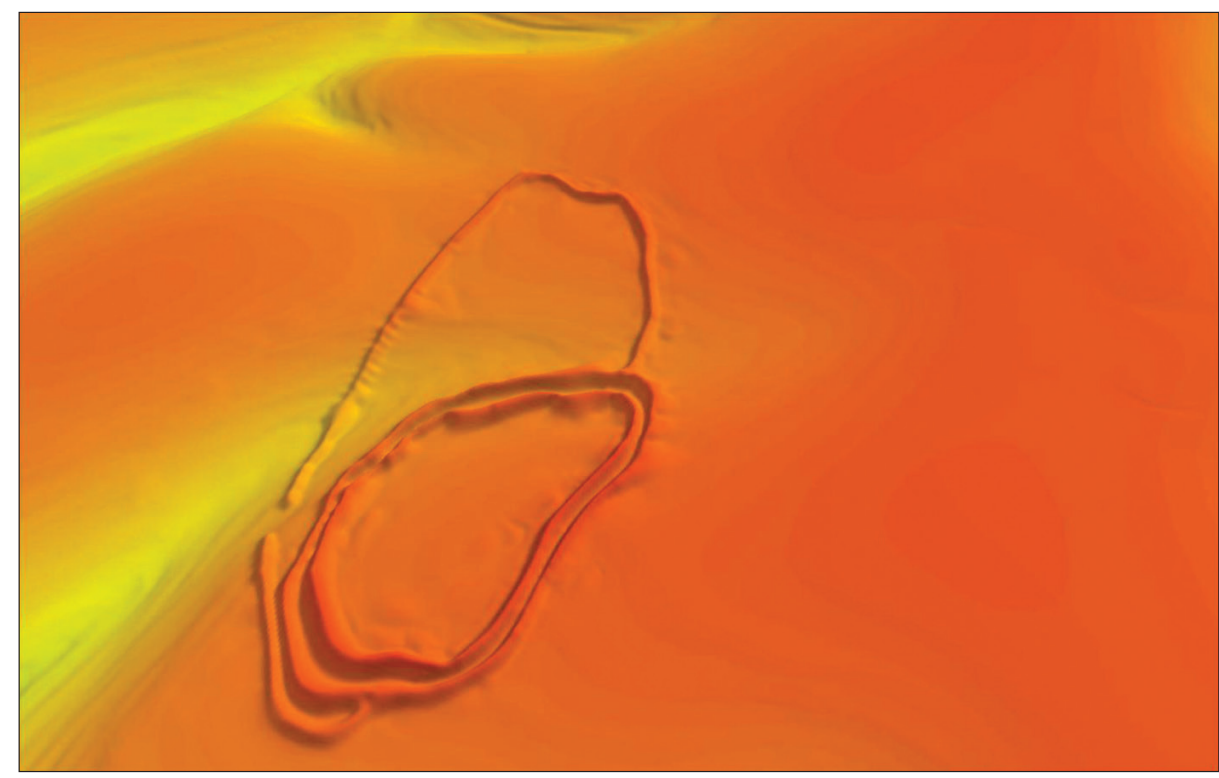

Fig. 20. Yakushyntsi, Vinnytsia Oblast. 2.5D model representing the fortified settlement from the west. Source: Author's work

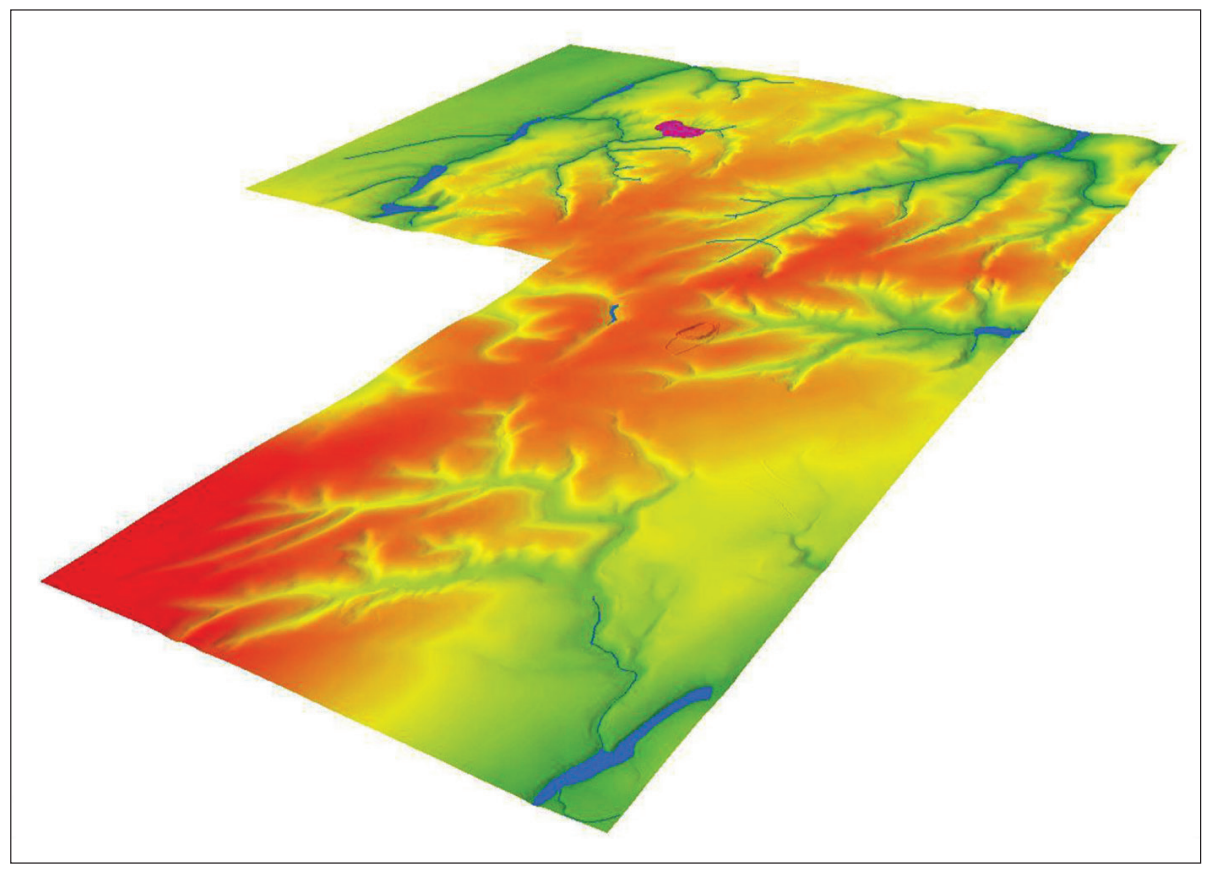

Fig. 21. Yakushyntsi, Vinnytsia Oblast. 2.5D model representing the fortified settlement with surrounding area and marked location of the gord in Pereorky from the south-west. Source: Author's work 


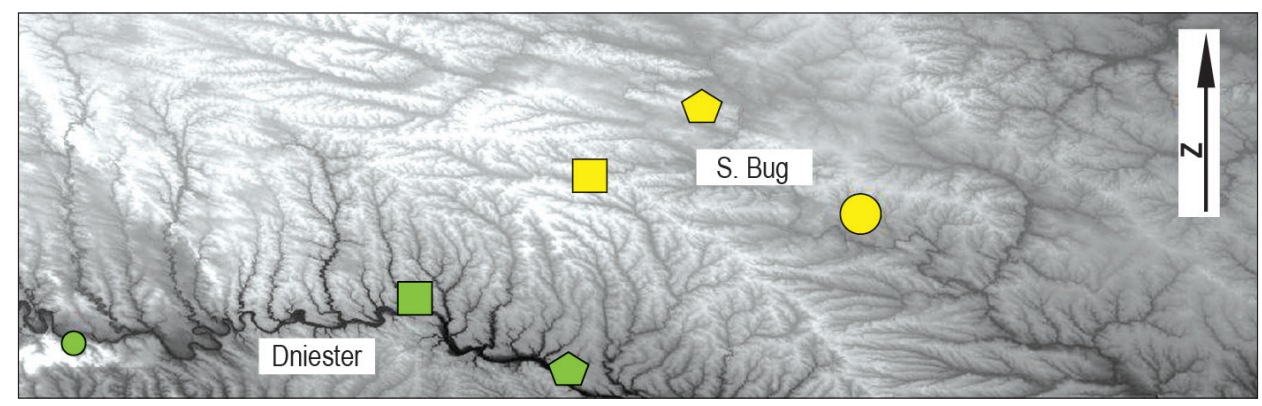

Fig. 22. Hryhorivka, Vinnytsia Oblast. Location of the site compared to the other analysed sites. Source: Author's work

Today there are two ponds through which the Ustia River flows (Fig. 30), but it is impossible to rule out the possibility of similar landscape existing in the early Iron Age. The stream flowing through the gord would have been a great backdrop for the possible numerous inhabitants and newcomers. During a siege it could provide water for large groups of people and animals that were then probably held inside the fortifications for protection. However, such a small river as Ustia is easy to dam up or poison and therefore, if the fortifications were also of military importance, the presence of said ponds appears to be justified and probable as for a long time they could have secured the water source for people and animals inside the fortifications.

There is no answer to why such an impressively large site was built in this particular place, away from the entire system. What was its purpose? Was it built for only basic functions like the production and accumulation of goods in the area or was there another superior goal? Without wider archaeological research it is difficult to find the answer.

This settlement is located westernmost out of all the aforementioned sites, $85 \mathrm{~km}$ away from the nearest site in Rudkivtsi (Fig. 31). It is situated on a higher ground within the distance of $1.5 \mathrm{~km}$ from the Dniester flowing in the south and is the only gord located on its right bank. The shape, like Nemyriv, resembles an oval and, accordingly, has one line of fortifications (Fig. 32). The site covers the area of 40 ha, which makes it the third largest of all six fortified settlements described in this paper.

The location of the site at some distance from the Dniester may bring up some questions (Fig. 33). Why was the site not located closer to the river, behind a vis- 


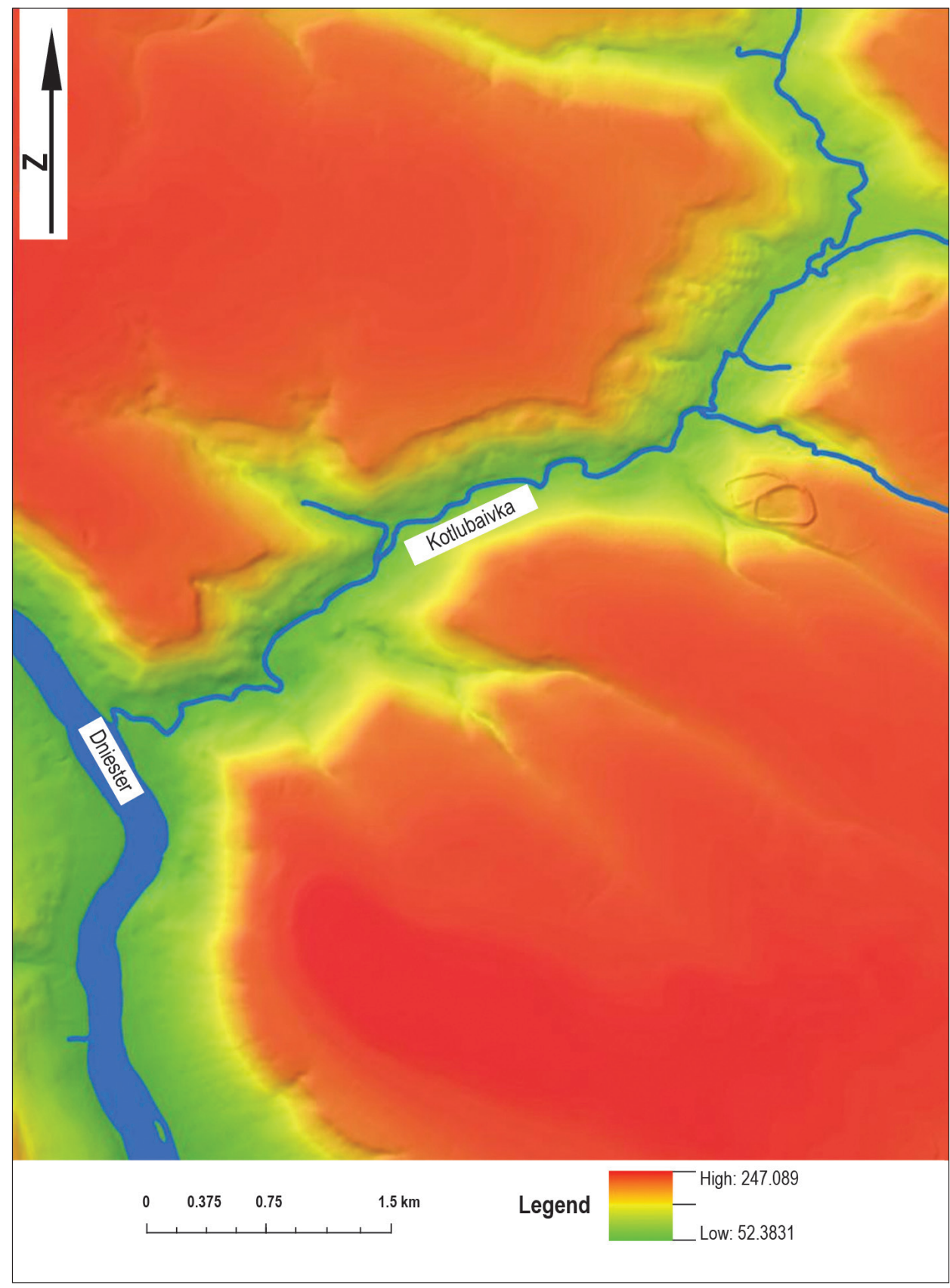

Fig. 23. Hryhorivka, Vinnytsia Oblast. The fortified settlement and the surrounding area. The Dniester, flowing in the north-south direction, appears on the west side of the map. Source: Author's work 


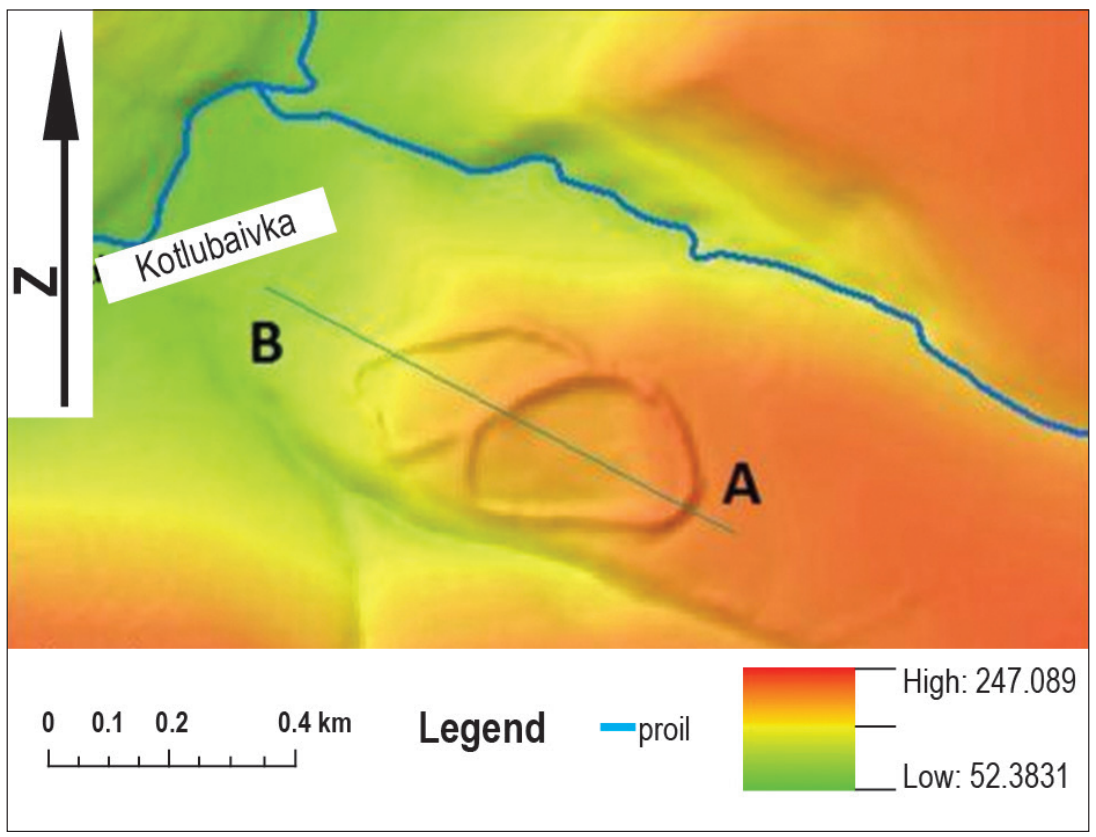

Fig. 24 . Hryhorivka, Vinnytsia Oblast. Locations of the sections of the fortified settlement. Source: Author's work

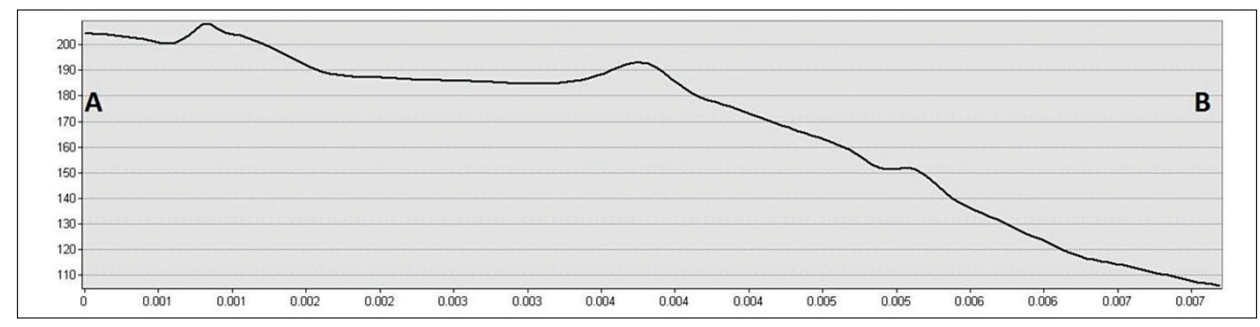

Fig. 25. Section of the site in Hryhorivka. Source: Author's work

ible ravine that would provide additional protection in case of attack? Such a location causes doubts about whether the site was of any military significance since it does not fully use the natural aspects of the terrain. One of the two rational explanations of this location seems to be the assumption that this place had some internal access to water and had no such possibility to collect it anywhere closer to the Dniester.

The second possible explanation is that there used to be an open settlement and pastures by the river and the settlement itself was rather a large defensive for- 


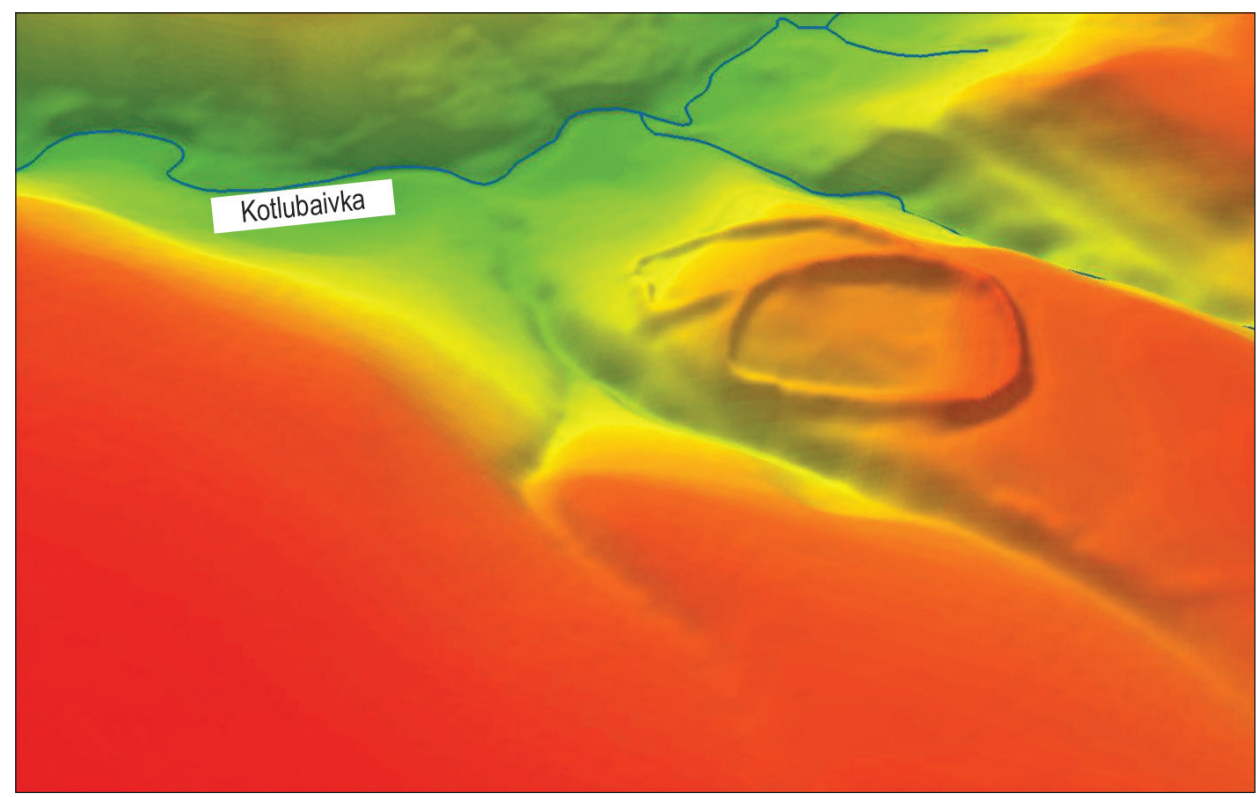

Fig. 26. Hryhorivka, Vinnytsia Oblast. 2.5D model representing the fortified settlement, view from the south, with the Kotlubaivka River showing in the background. Source: Author's work

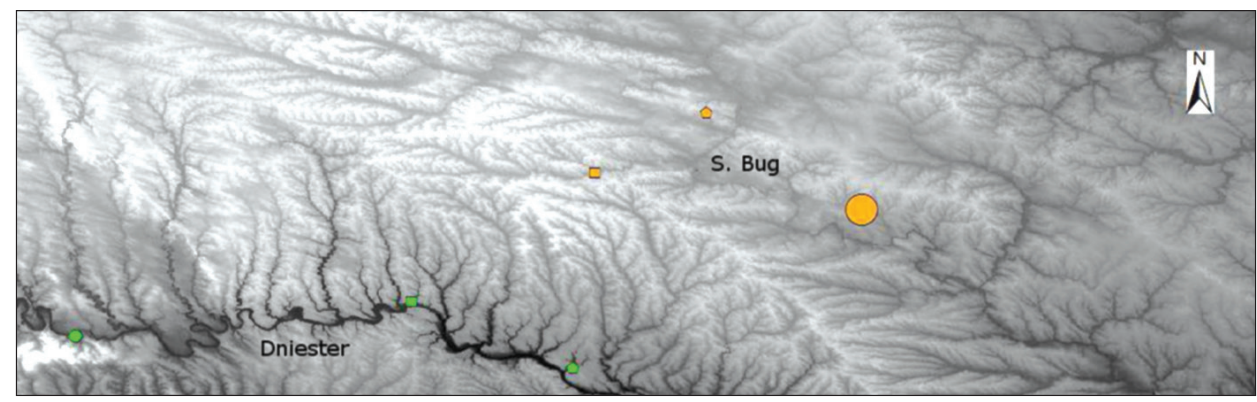

Fig. 27. Nemyriv, Vinnytsia Oblast. Location of the site in Nemyriv compared to the other analysed sites. Source: Author's work

tress, protecting the area. Of course, there may have been other premises, but in the absence of extensive archaeological research of the site and its surroundings they are impossible to verify [Moruzhenko 1969; Shelekhan 2011; Lawniczak 2013]. 


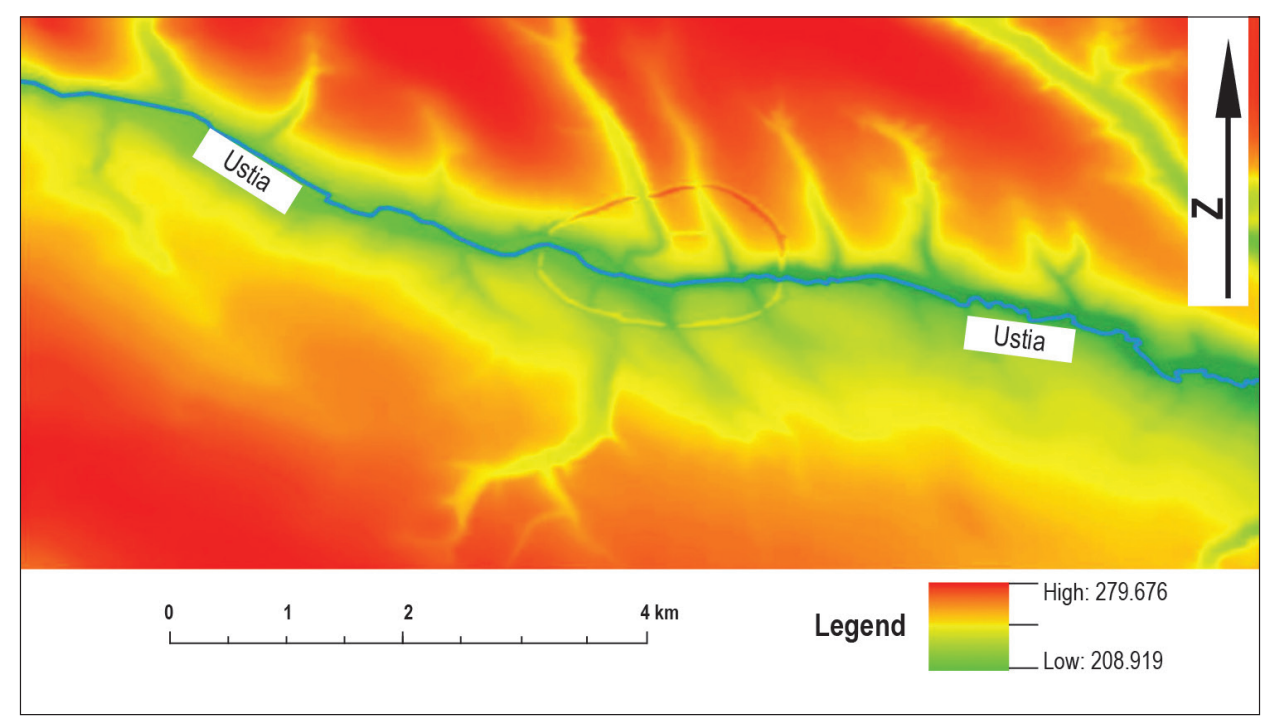

Fig. 28 . Nemyriv, Vinnytsia Oblast. The fortified settlement with the surrounding area. River appears in the centre of the drawing. Source: Author's work

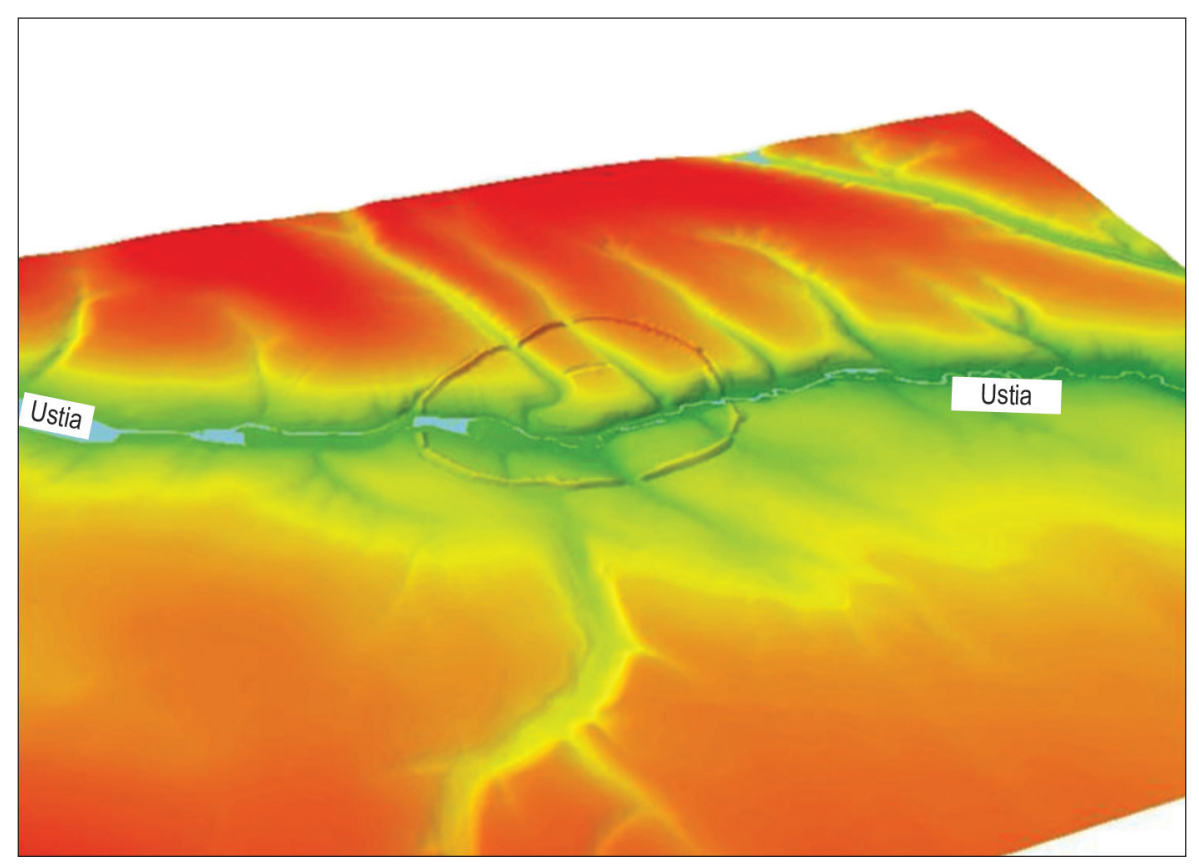

Fig. 29. Nemyriv, Vinnytsia Oblast. 2.5D model showing the fortified settlement and its south-west surroundings. Natural ravines divide the site into eight "districts". Source: Author's work 


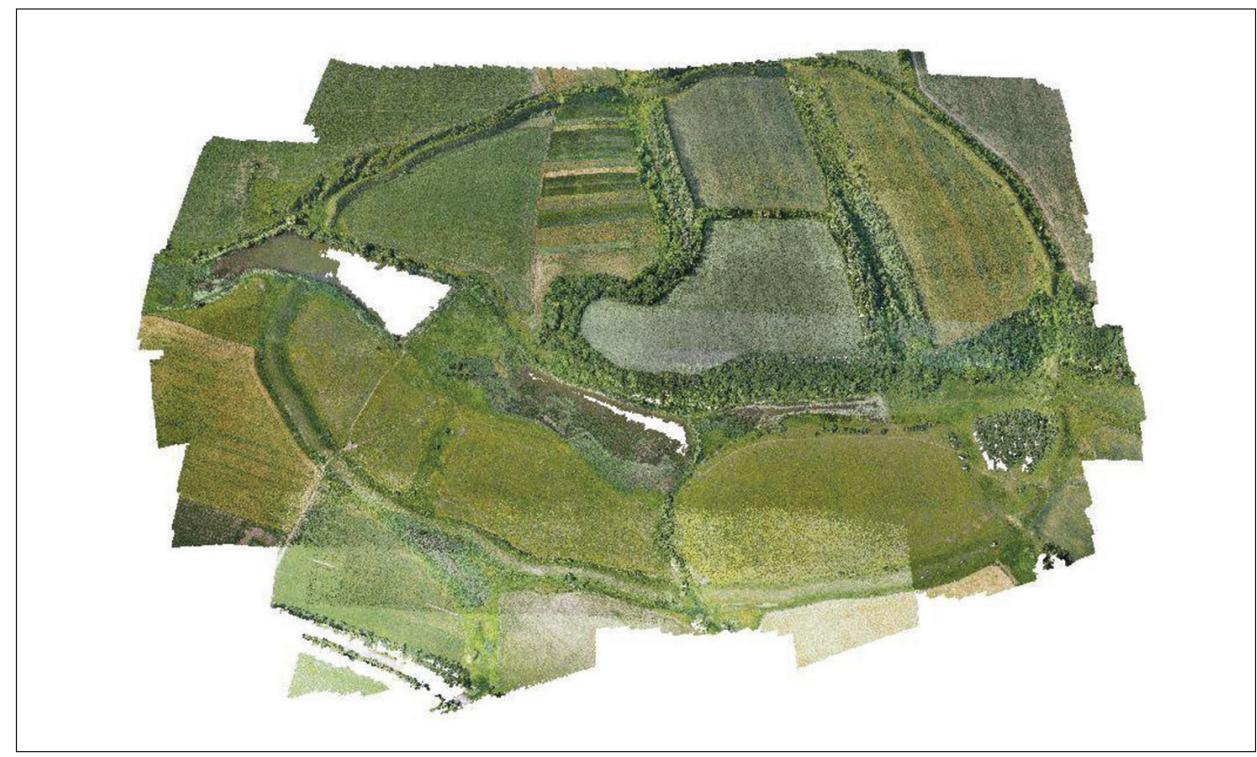

Fig. 30 . Nemyriv, Vinnytsia Oblast. Point cloud representing the gord from the south. Oval-shaped fortifications are clearly visible. Two ponds, currently present in the landscape, are visible as well as a shoe-shaped place called "the Burgstall". Source: Author's work

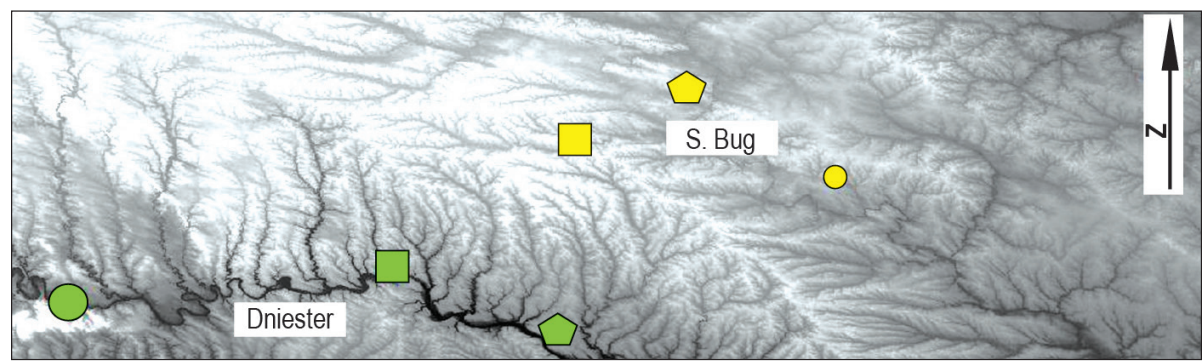

Fig. 31. Location of the site in Severynivka compared to other analysed sites. Source: Author's work

Ta b I e 2

Basic characteristics of six analyzed fortified settlements

\begin{tabular}{|l|l|l|l|}
\hline Name & Size & Fortifications & River basin \\
\hline Severynivka & $5.5 \mathrm{ha}$ & Rectangular & Southern Bug \\
\hline Rudkivtsi & $40.5 \mathrm{ha}$ & Rectangular & Dniester \\
\hline Yakushyntsi & $12.5 \mathrm{ha}$ & Two-part & Southern Bug \\
\hline Hryhorivka & $10 \mathrm{ha}$ & Two-part & Dniester \\
\hline Nemyriv & $125 \mathrm{ha}$ & Oval & Southern Bug \\
\hline Rukhotyn & $40 \mathrm{ha}$ & Oval & Dniester \\
\hline
\end{tabular}

Source: Author's work 


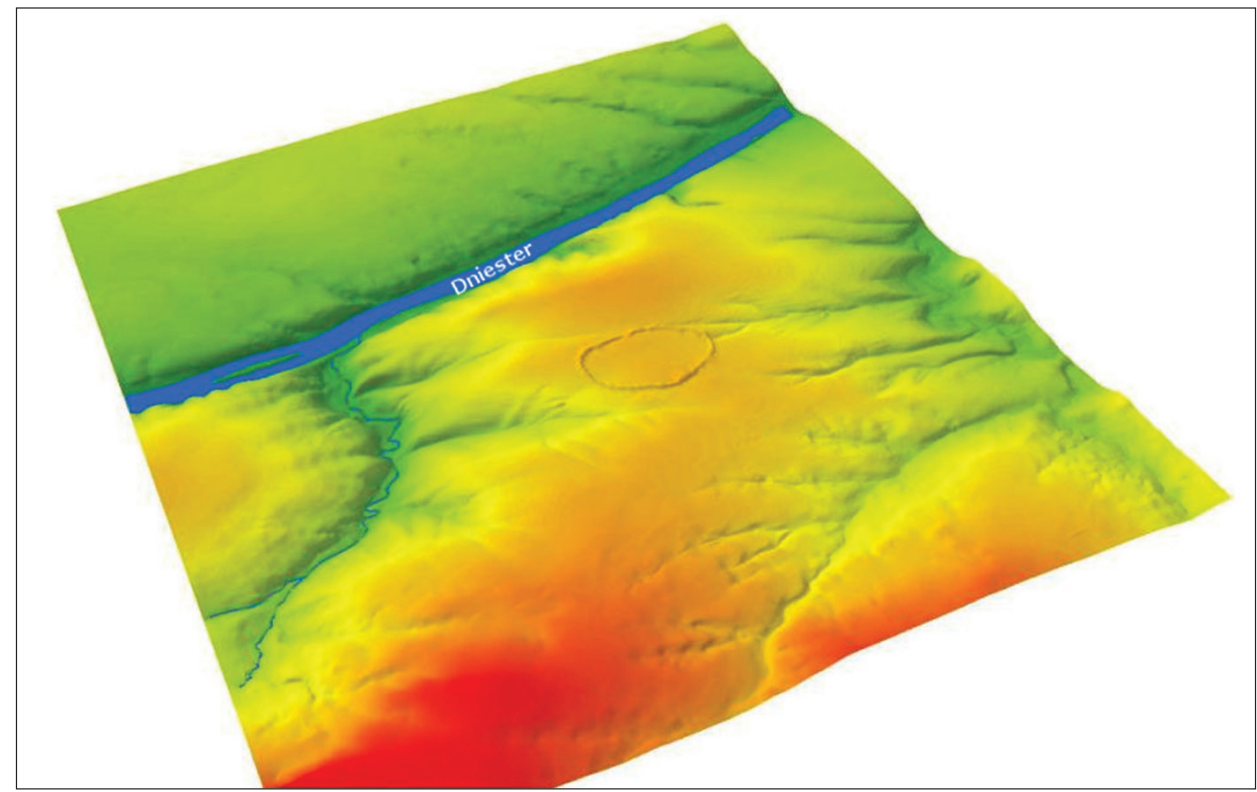

Fig. 32. Rukhotyn, Chernivtsi Oblast. 2.5D model showing the fortified settlement and its south-west surroundings. The Dniester, which flows from east to west appears in the north. Source: Author's work

CONCLUSIONS

Based on the observation of the six fortified settlements, one can notice some corelations but the above analysis also raises new questions.

- There are three types of sites that can be observed in terms of form and location: rectangular on forelands, two-parted with a raised proper gord and sloped borough and oval in relatively flat areas (Tab. 2).

- It seems that the region where the site is located is not of great significance, which means that there is no situation where one type of a site is exclusive to one area, only e.g. rectangular fortified settlements in the Southern Bug basin and two-parts near the Dniester (Tab. 2).

- Based on spatial observation alone, it is not possible to judge why the specific location was chosen. In the surroundings of most of aforementioned sites any other form would be possible to build. Perhaps there was an additional purpose for these particular forms but it is impossible to identify or interpret it without accurate archaeological research. 


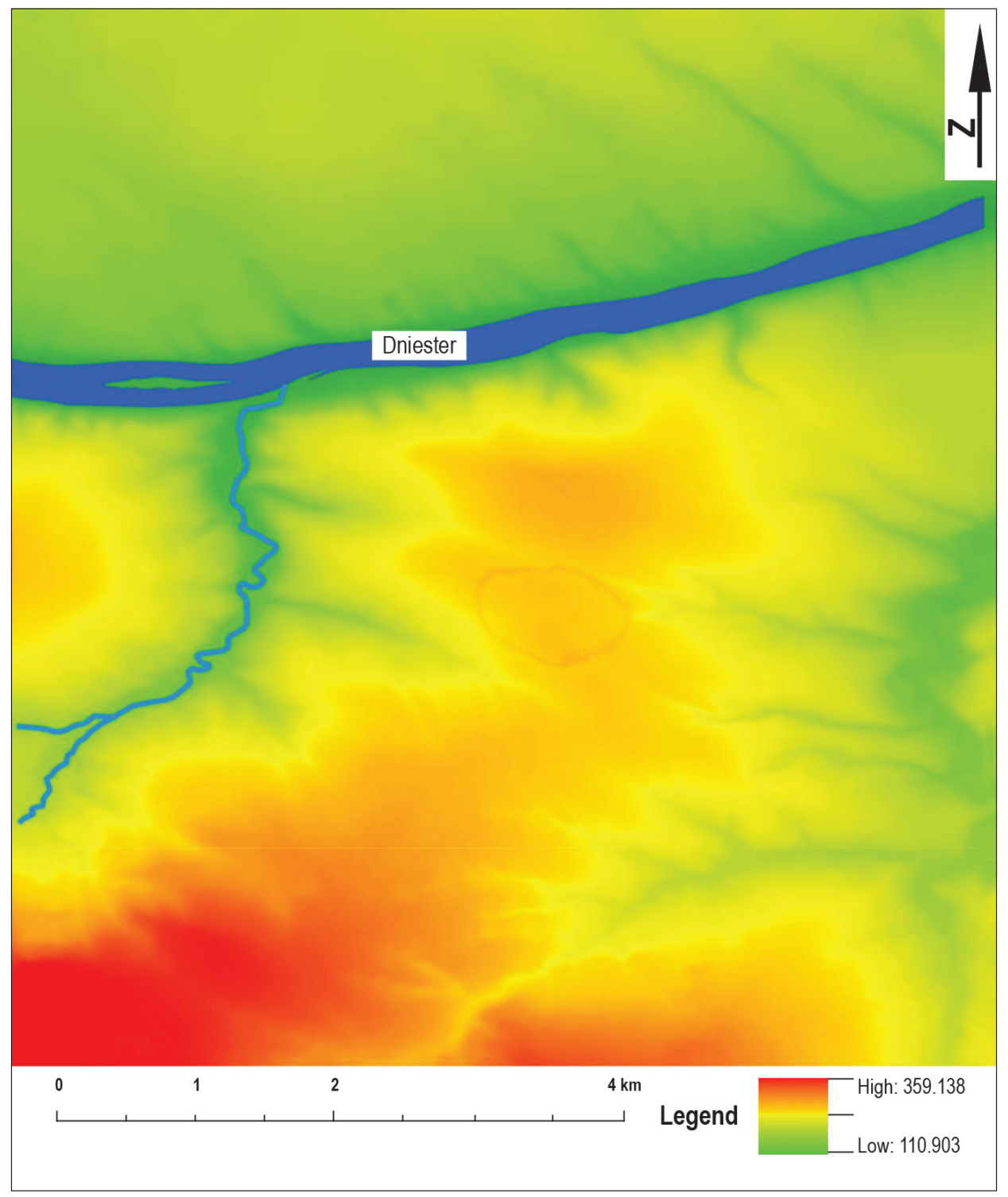

Fig. 33. Rukhotyn, Chernivtsi Oblast. The fortified settlement with its surrounding area. What is interesting, is that the site is located at a distance from the river Dniester, which may suggest that the gord was separating the southern watershed from its last part, the elevated ground, just by the river. Source: Author's work 
- Oval fortified settlements are the largest ones. However it is likely that this thesis is incorrect because of the small number of analysed sites and with a broader perspective the conclusions may differ.

- All sites are located on the border of two environmental systems. Usually they are located on the edge of the landforms, on elevated grounds and watersheds, near the river valleys and the rivers themselves. The exception in this case is the gord in Nemyriv, which is situated within higher areas separated by a valley of the Ustia River, flowing through the site.

- There is no visible standardization of the form, e.g. Severynivka is a small site while Rudkivtsi is a much larger one. Yakushyntsi along with the Pereorky are located near the important river crossing while Hryhorivka is not. Even if one assumes that there was a crossing through Dniester the questions of why Rudkivtsi and Rukhotyn do not have a similar form arises?

Translated by Anna Sokołowska 


\section{REFERENCES:}

\section{Daragan M.N.}

2010 Geoinformatsionnyi analiz transformatsii poselencheskikh struktur $w$ nachale rannego zheleznogo veka $v$ Srednem Podneprove: sostoyanie problem i perspektivy issledovaniya (held in archives of IA NANU).

Herodotus

1959 Dzieje. Tłumaczenie i opracowanie S. Hammera. Warszawa.

\section{Hutsal A.F.}

2000 Rudkovetske horodyshche i pershyi pokhid skifiv u prydnistrovskyi lisostep. In: Davnia i serednovichna istoriya Ukrayiny, 69-93. Kamianets-Podilskyi.

Ławniczak M.

2013 Grodziska wczesnoscytyjskie prawobrzeżnej Ukrainy. Zagadnienia ewidencji oraz systematyki (held in the archives of Adam Mickiewicz University). Poznań.

Moruzhenko A.O.

1969 Horodyshcha skifskoho chasu na teritorii lisostepu Skhidnoi Yevropy. Visnyk Kharkivskoho universytetu 3: 65-73.

\section{Shelekhan O.V.}

2011 Oboronni sporudy Severynivskoho horodyshcha skifskoho chasu v baseyni r. Pivdennyy Buh. Mahisterium. (Arkheolohichni studiyi) 45: 55-59. 